\title{
COMPETIÇÃO POR NUTRIENTES ENTRE A CULTURA DO ARROZ E A COMUNIDADE INFESTANTE. EFEITOS DO ESPAÇAMENTO E DA FERTILIZAÇÃO NITROGENADA
}

\author{
ROBINSON ANTONIO PITELLI
}

Orientador: HENRIQUE PAULO HAAG

Tese apresentada à Escola Superior de Agricultura "Luiz de Queiroz" da Universidade de São Paulo, para obtenção do titulo de Doutor em Agronomia. Área de Concentração: Solos e Nutrição de Plantas.

P I R A C I C A B A

Estado de São Paulo - Brasil

Dezembro - 1981 
Aos meus pais, CAETANO

$$
\text { e MARIA AMALIA, }
$$

A MARIA ANGELICA, minha espôsa, ROBINSON LUIZ E ANGELICA MARIA, meus filhos 
$\mathrm{H} O \mathrm{M} E \mathrm{E} N \mathrm{~A}$ G E M

A Escola Superior de Agricultura "Luiz de Queiroz" pelos seus 80 anos.

A Faculdade de Ciēncias Agrárias e Veterinārias de Jaboticabal

pelos seus 15 anos.

e ao

Dr. Gilberto Diniz de Oliveira

por tudo que representa a todos nós. 
AGRADECIMENTOS

Agradeço a todos que, direta ou indiretamente, contribuiram na execução deste trabalho, e especialmente:

Ao professor Dr. HENRIQUE PAULO HAAG, pela orientação, amizade e atenção,

Ao Eng: Agro EVANILDO PERES DOMINGUES e ao acadê mico EDIVALDO DOMINGUES VELLINI, pela inestínável colaboração na - condução da fase experimental;

Aos colegas MS. EUCLIDES BRAGA MALHEIROS, Dr. PAULO AFONSO CLAÜDINO PEDROSO, Dr. DILERMANDO PERECIN E MS. GO DOFREDO CESAR VITTI, pelas sugestões e manifestação de apoio;

Aos professores e funcionários do setor de NUTRI ÇÃO DE PLANTAS do DEPARTAMENTO DE QUIMICA da Escola Superior de Agricultura "Luiz de Queiroz"-USP, pelos auxilios prestados, su․ gestões e manifestações de apoio.

Aos professores e funcionários do DEPARTAMENTO DE BIOLOGIA APLICADA À AGROPECUÁRIA da Faculdade de Ciências Agrá rias e Veterinárias de Jaboticabal - UNESP, pelos auxílios pres tados, sugestōes e manifestação de apoio;

Aos Estagiários do LABORATÓRIO DE ECOLOGIA AGRI COLA, do Departamento de Biologia Aplicada à Agropecuária da Fa cụldade de Ciências Agrárias e Veterinárias de Jaboticabal-UNEș, 
pela inestimāvel colaboração;

A Srta. MARIA RENATA MIGLINO pela inestinável co laboração nos serviços de datilografia e amizade;

A minha espôsa, MARIA ANGÊLICA, pela dedicação, incentivo e confiança. 
INDICE

Pāgina

1. RESUMO $\ldots \ldots \ldots \ldots \ldots \ldots \ldots \ldots \ldots \ldots \ldots \ldots \ldots \ldots \ldots$

2. INTRODUÇÃO

3. REVISÃO DE LITERATURA

4. MATERIAL E MÉTODOS

5. RESULTADOS E DISCUSSÃo $\ldots \ldots \ldots \ldots \ldots \ldots \ldots \ldots$

6. CONCLUSÕES

68

7. SUMMARY

8. IITERATURA CITADA $\ldots \ldots \ldots \ldots \ldots \ldots \ldots \ldots \ldots \ldots$ 


\section{IISTA DE TABELAS}

Tabela

01. Espaçamentos entre sulcos de semeadura, doses de cobertura nitrogenada e condições de manejo da comunidade infestante, a que foi submetida a cul tura do arroz de sequeiro ..............

02 Efeitos do espaçamento entre sulcos de semeadura de arroz e da fertilização nitrogenada sobre os teores de nutrientes na parte aérea de Digitaria sanguinalis I: por ocasião do perfilhamento da cultura. Média de 4 repetições .. . . . . . ..

03 Efeitos do espaçamento entre sulcos de semeadura de àroz e da fertilização nitrogenada sobre os teores de nutrientes na parte aérea de Indigofe ra hirsuta L. por ocasião do perfilhamento da cultura. Média de 4 repetições .. . . . . . . ..

04 Efeitos do espaçamento, da fertilização nitroge nada e da competição das plantas daninhas sobre os teores de nutrientes na partẹ aérea das plan tas de arroz por ocasião do início do perfilha mento. Média de 4 repetições ... . ......... . 
05 Efeitos do espaçamento entre sulcos de semeadura de arroz e da fertilização nitrogenada sobre os teores de nutrientes na comunidade infestante por ocasião por florescimento da cultura. Média de 4

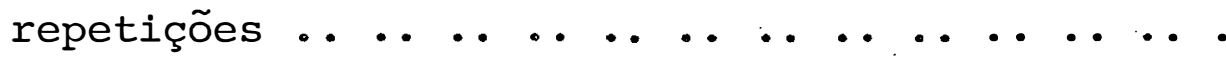

06 Efeitos do espaçamento da fertilização nitrogena da-e da competição das plantas daninhas sobre os teores de nutrientes na parte aérea de plantas de arroz por ocasião dọ florescimento. Média de 4 repetições .. . . . . . . . . . . . . . . . . . . .

07 Efeitos do espaçamento entre sulcos de semeadura de arroz e da fertilização nitrogenada sobre a quantidade de matéria seca e de nutrientes acumu lada pela comunidade infestante em 1 hectare, por ocasião do florescimento da cultura. Média de 4 repetições . . . . . . . . . . . . . . . . . . . .

08 Efeitós do espaçamento entre sulcos de semeadu ra, da fertilização nitrogenada e da competição das plantas daninhas sobre a quantidade de maté ria seca e de nutrientes acumulado na parte aê rea do arroz em 1 hectare. Média de 4 repetições.

09 Efeitos do espaçamento em sulcos de semeadura, da fertilização nitrogenada e da competição das 
plantas daninhas sobre as quantidades de matéria seca e de nutrientes acumulados por metro de li nhà de semeadura do arroz, por ocasião do flores cimento. Média de 4 repetições ............

10 Efeitos do espaçamento entre sulcos de semeadura, da fertilização nitrogenada e da competição das plantas daninhas sobre a quantidade de matéria se ca e de nutrientes acumulados no sistema em 1 hec tare. Média de 4 repetições .. . . . . . . . . . .

11 Efeitos do espaçamento e da fertilização nitroge nada sobre a participaçäo percentual do arroz na matéria seca ou nas quantidades totais de nutrien tes acumulados em 1 hectare, por ocasião do flo rescimento. Média cie 4 repetições .. . . . .....

12 Efeitos do espaçamento entre sulcos de semeadura, da fertilização nitrogenada e' da competição das plantas daninhas sobre os teores de nutrientes na matéria seca de grãos de arroz beneficiados. Mé dia de 4 repetições... . . . . . . . . . . . . . .

13 Efeitos do espaçamento entre sulcos de semeadura, da fertilização nitrogenada e da competição das plantas daninhas sobre as quantidades de nutrien tes presentes na produção por hectare de grãos be 
neficiados de arroz. Média de 4 repetições .. .. . 65 


\section{LISTA DE FIGURAS}

Figura

01 Amplitude das variações térmicas (linhas verti cais), temperaturas médias diārias (linha con tínua) e precipitaçõs diārias (barras vertị cais), ocorridas no mês de outubro de 1980 na FCAV/UNESP, Jaboticabal. Temperatura média men sal de $24,0^{\circ} \mathrm{C}$ e precipitação total do mês 99,3 $\mathrm{mm} \ldots \ldots \ldots \ldots \ldots$

02 Amplitude das variações térmicas (linhas ver ticais), temperaturas médias diārias

(linha contínua) e precipitações äiärias (barras ver ticais), ocorridas no mês de novembro de 1980 na FCAV/UNESP, Jaboticabal. Temperatura média mensal de $23,7^{\circ} \mathrm{C}$ e precipitação total do mês $267,9 \mathrm{~mm} \ldots \ldots \ldots \ldots$

03 Amplitude das variações tērmicas (linhas ver ticais), temperaturas médias diārias (linhas contínua) e precipitações diärias (barras ver tícais), ocoirridas no mês de dezembro de 1980 na FCAV/UNESP, Jaboticabal. Temperatura mëdia mensal de $23,8^{\circ} \mathrm{C}$ e precipitação total do mês $270,6 \mathrm{~mm} \ldots \ldots \ldots \ldots \ldots$ 
Figura

Pāgina

04 Amplitude das variações térmicas (linhas verti cais), temperaturas médias diārias (linha con tĩnua) e precipitações diārias (barras verti cais), ocorridas no mēs de janeiro de 1981 na FCAV/UNESP, Jaboticabal. Temperatura média men sal $23,8^{\circ} \mathrm{C}$ e precipitação total do mềs $324,4 \mathrm{~mm}$.

05 Amplitude das variaçôes térmicas (linhas verti cais), temperaturas médias diārias (linha con tînua) e precipitações diārias (barras vertí cais), ocorridas no mês de fevereiro de 1981 na FCAV/UNESP, Jaboticabal. Temperatura mëdia mensal $24,6^{\circ} \mathrm{C}$ e precipitação total do mês 90,9 $m$ 
1. RESUMO

Objetivou-se èstudar os efeitos das diferenças de $0,40 \mathrm{~m}$ e $0,60 \mathrm{~m}$ e das doses de $2.4,4.8$ e $7.2 \mathrm{~g}$ de $\mathrm{N} / \mathrm{m}$ de sulco sobre a competição por nitrogenio, fósforo, potāssio, cālcio, mag nésio, cobre, ferro, manganês e zinco entre a comunidade infes tante e a cultura do arroz de sequeiro (Oryza sativa I. C.V.IAC 25). O experimento foi instalado em solo Latossol Vermelho Escu ro fase arenosa.

Coletou-se a parte aérea das plantas de arroz e das plantas daninhas no perfilhamento e no florescimento da cul tura. Analisou-se, ainda, o grão de arroz beneficiado.

Nas condições em que foi desenvolvida a presente pesquisa pode-se concluir que: 
1) A competição imposta pelas plantas daninhas reduziu os acúmulos de matéria seca e de nutrientes na parte aēṛea e nos grãos de arroz. A redução da produção de grãos foi da ordem de $60 \%$;

2) os acúmulos de matéria seca e de nutrientes pe. la comunidade infestante nầo foram alterados pelo espaçamento $e$ pela fertilizaçäo nitrogenada;

3) as participações do arroz e da comunidade in festante no total da matéria seca acumulada no sistema foram e quilibradas;

4) a comunidade infestante e a cultura divergiram no recrutamento dos recursos minerais do solo. O arroz apresen tou teores mais elevados de fósforo, cobre, manganês e zinco. Os teores de nitrogênio, potássio, cálcio, magnésio e ferro foram maióres na comunidade infestante;

5) a intensidade de influēncia das plantas dani nhas em relação aos teores dos elementos no arroz foi maior no espaçamento de $0,60 \mathrm{~m}$ e dependeu do nîvel de exigência dos com petidores em relação aos elementos. 
2. INTRODUÇÃO

A cultura do arroz (Oryza sativa L.) como qual quer população vegetal ou animal, está sujeita à uma sé̉rie de fa tores do meio ambiente que atuam sobre o seu crescimento e desen volvimento, e, juntamente com sua expressão genotípica, irão de terminar a sua morfologia é produtividade.

Dentre estes fatores ambientais, a competição im posta pelas plantas daninhas destaca-se como um dos mais impor tantes. A cultura e a comunidade infestante praticamente utili zam dos mesmos recursos para crescimento e desenvolvimento e, quando estes são limitados, a competição se instala acarretando prejuîzos quantitativos e qualitativos na produtividade econômi ca da cultura e também no crescimento e capacidade reprodutiva 
das plantas daninhas.

A intensidade dos efeitos da competição depende da intervenção de inúmeros fatores, alguns ligados à cultura (es pécie, variedade ou cultivar, espaçamento entre sulcos e densi dade de semeadura) e outros ligados à comunidade infestante (com posição específica, densidade e distribuição das plantas dani nhas). Além disso, depende também da época e duração do perỉodo que permanecem juntas a cultura e a comunidade infestante e é mo dificada pelas condições edáficas, climáticas e de tratos cultu rais. Embora na prática, apenas o período e época de convivência tenham sido controlados todos esses fatores são passíveís de coṇ trole:

O controle do perĩodo de convivência múltipla nor malmente é feito através de cultivós manuais ou mecânicos, ou ainda, atravēs da aplicação de produtos herbicidas. Entretanto, nos ültimos anos, com a crise energética, o crescente êxodo ru ral e o enćarecimento dos herbicidas, o controle de plantas da ninhas passou a assumir uma expressäo bastante significativa no balanço custo-receita, principalmente para a cultura do arroz de sequeiro que, além de bastante susceptível às variações climá ticas, apresenta baixa produtividade nestas condições. Por estes e por outros motivos, atualmente procura-se estudar mais detalha damente o balanço competitivo da cultura com a comunidade infes tante, tentando-se alterá-lo a favor da primeira e, com isso, re duzir a intensidade das medidas de controle.

Para a cultura do arroz, uma das estratégias tes 
tadas para esta alteração no balanço. competitivo è o incremento de sua capacidade de sombreamento. Para tanto, testam-se diferen tes cultivares, alterações de espaçamento e na densidade de se meadura, ap̣licação de fertilizantes e outros.

Em sua maioria, os resultados são avaliados em termos da consequência da competição atravēs de caracterīsticas morfológicas como perfilhamento, porcentagem de perfilhos fér teis, número de grãos por panícula, produção de grãos e outros. são poucos os trabalhos que procuram avaliar a intensidade de competição pelos recursos essenciais ao desenvolvimento dos com petidores, como água, luz e nutrientes.

O presente trabalho de pesquisa procurou estudar os efeitos de dois espaçamentos entre sulcos de semeadura e três doses de fertilização nitrogenada sobre a competição por nitrogê nio, fósforo, potássio, cálcio, magnēsio, cobre, ferro, manganês e zinco entre a cultura do arroz de sequeiro, cultivar IAC-25, e a comunidade infestante. 
3. REVISÃO DE LITERATURA

As relações competitivas entre a cultura comer cial e a comunidade de plantas daninhas que se desenvolve na mesma ārea, foram esquematizadas por BLEASDALE (1960), sendo o esquema modificado por BLANCO (1972). Neste tipo de relação, observa-se a competição entre uma população, de indivỉduos relatị vamente semelhantes, e uma comunidade, composta de inúmeras popu lações, diferentes tanto em termos qualitativos como quantitati vos. Esta heterogeneidade confere à comunidade uma maior estabi lidade em termos de recrutamento de recursos do meio e menor susceptibilidade a diferentes alterações de seu ambiente. Este aspecto dificulta sobremaneira a alteração do balanço competiti vo a favor da cultura. Alguns resultados contraditórios encontra 
dos na literatura, são explicados pelas composições especĩficas das comunidades infestantes que variam bastante de local para lo cal e, no mesmo local, de um ano agrícola para o outro.

Dentre as estratégias pesquisadas visando a alte ração deste balanço competitivo a favor da cultura do arroz, o aumento da velocidade e da intensidade de sombreamento tem rece bido destaque. TAKAYANAGI et alii (1974) observaram, na cultura do arroz inundado, que a competição por luz é determinada pela distribuição-vertical da área foliar, pelas formas do fluxo da radiação solar nas várias camadas da cultura e pela fotossintese bruta da folhagem. KAWANO et alii (1974) observaram que, dentre outras, as caracteristicas das plantas que mais correlacionavam com sua capacidade competitiva eram viegor vegetativo, extensa área foliar e altura dạ planta, todas relacionadas à sua capací dade de sombreamento.

JENNINGS (1966) acredita que em certas regiões tropicais e de agricultura pouco adiantada, o sucesso das tradi cionais variedades altas deve-se basicamente à sua maior capaci dade de limitação do crescimento da comunidade infestante. YOSHI DA (1977) observou que as cultivares altas crescem tanto ou mais que a comunidade e, com isso, além de sofrer menor competição por luz, exerce-a em maior grau. A maior capacidade competitiva das cultivares altas em relação às baixas também foi observada por BRADY (1979) e MERCADO \& LUBIGAN (1979).

Além da altura, o posicionamento das folhas é im portante na determinação da capacidade competitiva da planta 
(SINGLACHAR, et alii, 1978). Segundo YOSHIDA (1977) geralmente cultiva res altas têm folhas pendentes, o que aumenta sua capacidade de sombreamento, quando comparado com as baixas que geralmente apre Sentam folhas eretas. AHMAD et alii (1977) observaram este efei to, quando compararam a cultivar Basmati (alta e de folhas pen dentes) com IR 6-945 (baixa e de folhas erectas). YOSHIDA (1977) observou que um modérado suprimento de nitrogênio é importante na òbtençāo deste efeito. Quando as plantas são deficientes nes te elemento, as folhas crescem pouco e ficam eretas e a capacida de de sombreamento é diminuída.

A densidade e a distribuição geográfica da popula çao de arroz na área cultivada, têm influência decisiva na compe tição contra as plantas daninhas, principamente através da inten sidade de interceptação dos raios solares. SARKAR (1979) e YAMA GISHI et alii (1976) observaram que maiores espaçamentos na cul tura do arroz, permitiam maiores densidades e acúmulos de matéria seca pela comunidade infestante. MERCADO \& LUBIGAN (1979) e KIM \& MOODY (1980) observaram que em espaçamentos menores, a eficiên cia do controle químico ou manual era maior, devido ao efeito complementar da cultura.

O efeito do sombreamento sobre a supressão do crescimento das plantas daninhas depende bastante da composição especifica da comunidade infestante, pois as espécies respondem diferencialmente às diferentes limitações da radiação solar (No .GUSHI \& NAKAYAMA, 1978b). Com efeito, GUH (1973), observou, em arroz transplantado, que aumentando-se o número de plantas por 
feixe de transplante de uma para três, havia um aumento da inter cepção da luz solar e conseqüente decréscimo de plantas da famí lia Cyperaceae. Aumentando-se o número de três para cinco plan tas por feixe, houve redução da incidência de dicotiledôneas. De todas espécies presentes, Cyperus spp, Monochoria vaginalis (Burm) Presl; e Eriocaulum sp, foram extremamente sensiveis ao som breamento. KIM \& MOODY (1980) observaram que em espaçamentos de $20 \times 20 \mathrm{~cm}$ entre feixes de transplante, O Indice de Importância de Monochoria vaginalis decresceu drasticamente com os anos de cultivo na mesma ārea. No entanto, para Echinochloa glabrescens Munro Ex. Roob. F., este valor aumentou. Para esta espécie foi necessário um espaçamento de $10 \times 10 \mathrm{~cm}$.

Geralmente, quando é permitido que a comunidade infestante se desenvolva desde o inỉcio do ciclo da cultura, sem qualquer tipo de controle, este efeito de espaçamento pode ser. anulado, principalmente em-condições de semeadura direta. Isto deve-se ao fato de que, geralmente, a comunidade infestante tem um crescimento inicial mais intenso que a cultura, sombreando-a rapidamente. BANTILAN et a $i_{i}$ (1974) ressaltam que o efeito do espaçamento torna-se eficiente quando à germinação das plantas daninhas ocorre quando a cultura já apresenta uma certa capacida de de sombreamento, ou seja, após o último cultivo ou após efeito residual do herbicida aplicado. Em trigo, WILLIAMS (1977) observou que aumentanảo-se a fertilização nitrogenada havia um maior perfilhamento e consequentemente, maior poder de intercep ção da luz solàr e, com isso, o crescimento das plantas daninhas, 
que germinavam tardiamente, era sensivelmente diminuỉdo.

Outra estratégia pesquisada no sentido de alterar - balanço competitivo cultura-comunidade infestante é atravēs da aplicação de fertilizantes. A colocação do fertilizante dire tamente no sulco de semeadura constitui-se numa prática que au menta a capacidade competitiva da cultura, pois o acesso e utili zação do fertilizante fica dificultada à planta daninha. Em cana -de-açúcar, CERRIZUELA \& AREVALO (1974) observaram em parcelas mantidas no limpo, que quando a cobertura nitrogenada era realí zada ao lado da linha de plantio, as produções eram maiores quan do comparadas com a aplicação do fertilizante diretamente sobre a linha. No entanto, quando na presença de plantas daninhas, os melhores resultados foram obtidos com aplicações sobre a'linha.

$$
\text { NIETO \& STANIFORTH (1.961) e YAMAGISHI et alii }
$$

(1976) observaram que em altas taxas de fertilização, a competi ção por nutrientes pode ser eliminada, e a cultura poderá prodú zir bem, mesmo em solos infestados. NODA (1977) no entanto, con sidera que o manejo da fertilização do solo pode ser útil no con trole das plantas daninhas, mas na maioria das vezes, o fertili zante pode favorecer mais a comunidade infestante que a cultura.

Experimentos de vasos, sobre competição das plan tas de arroz com Cyperus iria L. (BANGLADESH, 1977) e com Echinoch Loa colonum (L.) Link. BANGLADESH, 1977 e LONG \& ALKAMPER, 1978), mostraram que a aplicação de fertilizantes favoreceu em maior intensidade o crescimento das plantas daninhas, incrementando as perdas de produção da cultura. 
FILIPINAS (1974), OKAFOR (1973)\& OKAFOR \& DE DATTA, (1976) observaram que a fertilização nitrogenada favoreceu em maior grau o crescimento de cyperus rotundus L. em relação ao arroz, incrementando as perdas de produção, principalmente devi do a um aumento na competição por umidade.

AHMAD et alii (1977) observaram que nỉveis modera dos de aplicação de nitrogênio aumentavam as perdas de produção da cultura, mas que este efeito diminuía em altas taxas de ferti lização. SMITH \& SHAW (1966) observaram que aplicações de fósfo ro e nitrogênio, estimulavam o crescimento das plantas daninhas em maior intensidade e aumentavạm a competição.

Sob este aspecto, vărios autores têm destacado a maior importância no controle das plantas daninhas em solos de alta fertilidade ou quando realizam-se pesadas adubações (CHANG, 1969; SWAIN et aZii, 1975; LONG \& ALKAMPER, 1978 e FILIPINAS, 1974; SWAIN et alii (1975) observaram reduções de produção da ordem de $64,4 \mathrm{~kg} / \mathrm{ha}$ por dia de competição em solos férteis, e 27,9 kg/ /ha/dia em solos de baixa fertilidade.

No entanto, o efeito da fertilização no balanço competitivo depende bastante das espécies de plantas daninhas envolvidas, pois estas respondem de maneira bastante diversas às aplicações de fertilizantes (FILIPINAS, 1974; MYERS \& MOORE, 1952; HO VELAND et alii, 1976 e BANTILAN et a $i i$, 1974). YAMAGISHI \& TA KEICHI (1978) observaram que a fertilização nitrogenada favore cia mais o arroz que Eleocharis kuroguwai ohwi aumentando seu potencial competitivo. 
Quando a espēcie daninha responde com menor inten sidade que a cultura ā aplicação de um fertilizante, este pode ser utilizado com um eficiente método de controle do crescimento da planta daninha, conforme verificaram BUA-NGAM \& MERCADO (1976) com Pistia stratiotes L. na cultura do arroz inundado.

KAWANO et alii (1974) observaram que a habilidade competitiva do arroz é negativamente correlacionada à capacidade de resposta da planta à fertilização nitrogenada. O autor expli ca este fato pela simples razão de que se a planta responde in tensamente a pequenos incrementos do fertilizante, também respon derá em igual intensidade a pequenas limitações do nutriente im postas pela competição. DE DATTA \& MALABUYOC (1976) mostraramque a cultivar IR 20 respondia intensamente à fertilização nitrogena da apenas nas parcelas mantidas rigorosamente no limpo. Quando em competição, as plantas daninhas anulavam, em parte, os efei tos da adubação.

A competição por nutrientes entre plantas dani nhas e a cultura do ärroz já foi estudada por inūmeros autores. GUH (1973) considera que o fator crỉtico è a habilidade que as mudas tem de iniciar o recrutamento dos fertilizantes do solo e com isso limitar a disponibilidade às plantas daninhas, além de impedir o desenvolvimento da comunidade infestante, atravēs de um crescimento predominante.

Vengris et alii (1963), citado por EL-SHAFEY et alii (1975) ressaltam que as plantas daninhas são capazes de acu mular elevadas quantidades de nutrientes, principalmente nitro 
gênio, fósforo e potāssio, e com isso diminuir a disponibilidade às plantas cultivadas. Com efeito, CHISAKA (1966) verificaramcor relação negativa significativa entre a quantidade de nitrogênio imobilizado pela comunidade infestante e o teor deste elemento na parte aérea de plantas de arroz. NODA (1973) observou que al tas infestaçöes de Echinochloa crusgalli (L。) Beauv. reduziam os teo res e as quantidades de nitrogênio acumulados na parte aérea do arroz.

Devido à grande variação ém termos do hảbito de crescimento existente entre as espēcies componentes das comuni dades infestantes, os teores de nutrientes em cada espēcie tem pouco valor em termos de determinação de seu potencial competiti vo. O porte da planta destaca-se como o mais importante. CICEREL LI et alii (1978) analisando algumas plantas infestantes da cul tura do milho, observaram que Acanthospermum hispidum DC., sem pre apresentou os teores mais elevados de nitrogênio, fósforo, potássio e magnésio, mas devido ao seu pequeno porte, apresentou a menor retirada destes nutrientes por individuo. Althernanthera ficoidea (L。) R. Br. foi a que apresentou o maior acúmulo de ma têria seca e dos nutrientes por indivĩduo.

ARAI \& KAWASHIMA (1956) observaram que Echinoch loa crusgalli causava maiores perdas de produção à cultura do -arroz que Monochoria vaginalis, quando as duas plantas daninhas encontravam-se em mesma densidade (50 plantas $\left./ \mathrm{m}^{2}\right)$, devido prin cipalmente ao maior porte da primeira. No entanto, quando se com parou biomassas equivalentes das duas espécies por ocasião do florescimento do arroz, as maiores perdas de produção foram ob 
servadas nas parcelas com Monochoria vaginalis. Acredita o

tor que a explicaçăo deste fato resida nos maiores teores de ni trogênio desta última que variou entre 1,46 a 2,53\%, ao

passo que na gramỉnea a variação foi entre 0,73 a 1,23\%.

KIM et alii (1977) observaram que em parcelas a 1 tamente infestadas, Ludwigia prostata Roxb. absorveu cerca de $90 \%$ do nitrogênio disponỉvel, ao passo que, em condições seme Ihantes, Monochoria vaginalis e Aneilema japonicum Kunth. absor veram $65 \%$, em suas respectivas parcelas.

MUKHOPADHYAY et alii (1972) observaram que infes tações severas de plantas daninhas removiarn do solo entre 36,4 e $37,1 \mathrm{~kg}$ de $\mathrm{N} / \mathrm{ha}$ e reduziam a produçăo do arroz em 74-988. As gra mỉneas compreendiam entre 85-898 do nümero de indivỉduos, entre 91 e $96 \%$ do total da matẽria seca e retinham entre 90 e $94 \%$ do total de $\mathrm{N}$ da comunidade infestante. Estes dados novamente res saltam a importância da biomassa das plantas daninhas que tem maior correlação com a quantidade de nutrientes recrutados.

PARFENYUK (1975) observou que elevadas infesta çōes de plantas do gênero Echinochloa spp extraỉram do solo 73,5 $\mathrm{kg}$ de $\mathrm{N} ; 64,5 \mathrm{~kg}$ de $\mathrm{P}_{2} \mathrm{O}_{5}$ e $130,2 \mathrm{~kg}$ de $\mathrm{K}_{2} \mathrm{O} / \mathrm{ha}$, enquanto que $\mathrm{o}$ ar roz extraiu 12,$9 ; 5,9$ e $16,1 \mathrm{~kg} / \mathrm{ha}$, respectivamente. KAUSHIK \& MANI (1977) verificaram que a competição das plantas daninhas provocou uma redução no acúmulo de nutrientes pela cultura do ar roz da ordem de $24,7 \mathrm{~kg}$ de $\mathrm{N} ; 5,8 \mathrm{~kg}$ de $\mathrm{P}$ e 63,4 kg de N/ha. KA KATI \& MANI (1977) observaram que, quando a semeadura foi direta, o decréscimo no acúmulo de nutrientes pelo arroz foi mais drás 
tico em relação ao arroz transplantado. Este fato reforça a ob servação de GUH (1973) de que uma mais rāpịda e intensa absorção de nutrientes nos estádios iniciais da relação competitiva pode favorecer a cultura.

WEILAND \& STUTTE (1972) observam que não é só a quantidade de nitrogênio acumulada pela comunidade infestante que determina seu potencial competitivo em relação a este nu triente, e ressaltam a importância das perdas do elemento pela transpiração das plantas daninhas. Sob este aspecto, compararam as perdas de alguns cereais e seis espécies de plantas daninhas. Estas ũltimas apresentaram em média, perda duas vezes e meia superior à das plantas cultivadas.

Pela presente revisão pode-se observar que o

as sunto è relativamente pouco estudado, principalmente em condi ções de sequeiro, uma vez que as referências apresentadas, en sua maioria referem-se a outros sistemas de cultivo, principal mente no regime inundado. No Brasil, destaca-se o trabalho de DOMINGUES (1981) que observou o efeito da competição das plantas daninhas, reduzindo, em alguns casos, os efeitos do espaçamento entre sulcos de semeadura e da fertilizaçăo nitrogenada em co bertura 。

Não se encontrou, na bibliografia consultada, qual quer referência a respeito dos efeitos de espaçamento e/ou fertí lização nitrogenada sobre a competição por nutrientes entre plan tas daninhas e a cultura do arroz de sequeiro. 
4. MATERIAI E METODOS

O presente ensaio foi instalado e conduzido na área experimental da Faculdade de Ciências Agrārias e Veterină rias-UNESP, "campus" universitārio de Jaboticabal. As coordena das geogrâficas do municipio são: latitude $21^{0} 15^{\prime} 22^{\prime S}$, longitude 48 $8^{\circ} 18^{\prime} 58^{\prime \prime}$ WGr e altitude de 575 metrós. O clima da região é o CWa segundo a' classificação de Koe"ppen.

o experimento foi instalado em solo classificado na unidade de mapeamento Latossol Vermelho Escuro fase arenosa (COMISSÃO DE SOLOS, 1960) e a nível de série classificado por ALOISI \& DEMATTE (1974) como incluĩdo na sērie Santa Tereza, cor respondendo ao sub-grupo "Typic Haplorthox" da 70 aproximaçäo. o solo inclue-se na classe textural barro argilo-arenosa, apresen 
tando $\mathrm{pH} 5,4$, contendo $0,66 \%$ de carbono, $6 \mu \mathrm{g}$ de $\mathrm{P}$ e $59 \mu \mathrm{g}$ de $\mathrm{K}^{+}$ $/ \mathrm{ml}$ de TFSA; 1,2 e 0,8 e.mg de $\mathrm{Ca}^{++}$e $\mathrm{Mg}^{++} / 100 \mathrm{ml}$ de T'FSA, res pectivamente. As análises foram efetuadas segundo metodologia des crita por RAIY \& ZULLO (1977).

A varidades de arroz semeada foi IAC-25, que para as condições do Estado de São Paulo, apresenta ciclo em torno de 110 a 120 dias e boa capacidade de crescimento e produção em con dições de sequeiro. E considerada como variedade de porte baixo e apresentä boa resistência ao "bruzone" (Pyricularia oruzae Cav。) .

Os tratamentos foram distribuidos segundo um es quema fatorial $2 \times 3 \times 2$ e encontram-se apresentados na Tabela 01 . Pela análise da tabela pode-se observar que as doses para a fer tilização nitrogenada foram calculadas com relação à únidade de linha de semeadura. Assim as quantidades do fertilizante por uni dade de superfície de solo variam, uma vez que houve 2 espaçamen tos entre sulcos. Procurou-se com isso, fornecer a cada indivî duo de arroz a mesma quantidade de nitrogênio adicionada nas respectivas doses, independente do espaçamento. Com esta mesma filosofia manteve-se a densidade de semeadura.

Para instalação do ensaio no campo, o solo, que no ano agrỉcola anterior havia sido cultivado com sorgo, sofreu aração em meados de junho para incorporação dos restos da cultu彑 ra anterior. Por ocasião de seu preparo para a instalação do en saio realizou-se mais uma aração e duas gradagens.

A distribuição dos tratamentos no campo obedecëu ao delineamento experimental de blocos casualizados, procurando- 
Tabela 01 - Espaçamentos entre sulcośs de semeadura, doses de co bertura nitrogenada e condições de manejo da comu nidade infestante, a que foi submetida a cultura do arroz de sequeiro.

\section{Cobertura}

Espaçamento

(m) nitrogenada

(g de $\mathbb{N} / \mathrm{m}$ )
Condição

de

manejo

0,40

2,4

limpo

0,40

2,4

mato

0,40

4,8

Iimpo

0,40

4,8

mato

0,40

7,2

limpo

0,40

7,2

mato

0,60

2,4

limpo

0,60

2,4

mato

0,60

4,8

limpo

0,60

4,8

mato

0,60

7,2

limpo

0,60

7. 2

mato 
-se maior uniformidade possivel dentro de cada bloco em termos de composição específica e densidade da comunidade infestante. E interessante esclarecer que, anteriormente à segunda aração, realizou-se uma avaliação visual da comunidade infestante na área com a finalidade de instalar adequadamente os 4 blocos ex perimentais.

As parcelas experimentais foram constituídas de 9 è 6 sulcos de semeadura de 4 metros de comprimento, respectiva mente para os espaçamentos de $0,40^{\circ}$ e $0,60 \mathrm{~m}$, perfazendo uma área total de $14,4 \mathrm{~m}^{2}$, dos quais considerou-se como ārea útil os $4,8 \mathrm{~m}^{2}$ centrais.

$\mathrm{Na}$ adubação de plantio, aplicou-se $0,24 \mathrm{~g}$ de $\mathrm{N}$, $3,6 \mathrm{~g}$ de $\mathrm{P}_{2} \mathrm{O}_{5}$ e $1,8 \mathrm{~g}$ de $\mathrm{K}_{2} \mathrm{O} / \mathrm{m}$ de sulco, nas formas de sulfato de amônio, superfosfato simples e cloreto de potássio, respecti vamente. A semeadura foi realizada 19/10/80, depositando-se, em média, 70 sementes por metro de sulco.

A adubação nitrogenada em cobertura, nas respecti vas doses, foì ef́etuada 35 dias após a semeadura (30 dias após a emergência). Para maior uniformidade na distribuição do adubo, utilizou-se de calhas metălicas onde o fertilizante era distri buído, posteriormente homogeneizado e, a seguir, a calha era entornada lateralmente à linha de semeadura do arroz, numa dis tância de $10 \mathrm{~cm}$ aproximadamente.

Nas parcelas mantidas no limpo, realizaram-se capi nas semanais até o término do primeiro terço do ciclo vegetativo do arroz (35 dias). A partir dai, as capinas passaram a ser rea 
lizadas a cada quatorze dias, pois a incidência de plantas dani nhas passou a ser menor devido à competição do arroz. Como a área experimental era relativamente isolada de outras áreas de plantio de arroz, a incidência de pragas e molētias foi baixa, não justificando a aplicação de qualquer defensivo agrî́cola.

No decorrer do ciclo da cultura, ao redor dos 60 dias após a emergência do arroz, houve a incidência de um verani co, ocasião em que as parcelas começaram a mostrar.sintomas de enrolamento das folhas, principalmente aquelas semeadas em meno res espaçamentos. Para evitar a interferência diferencial deste veranico nos diferentes tratamentos; optou-se pela irrigação da área utilizando-se equipamento de aspersão.

Os parâmetros climatológìicos de temperaturas mâ ximas, médias e mỉnimas e de precipitação diārias ocorridas du rante o ciclo da cultura foram obtidas junto ao posto meteoroló gico da Faculdade de Ciências Agrárias e Veterinárias, localizą do a aproximadamente $1 \mathrm{~km} \cdot$ do local. Estes dados estão sendo apre sentados gráficamente na figuras 1 e 5 .

Aos 50 dias após a emergência da cultura, época em que a cultura começava a apresentar o inỉcio do perfilhamento intenso, coletou-se aleatoriamente em cada parcela, a parte aé rea de algumas plantas de arroz e, nas parcelas no mato, também de alguns indivỉduos de Digitaria sanguinalis L. e de Indigofera hirsuta L., espécies que predominavam amplamente na comunidade infestante, tanto em termos numéricos como em matéria verde. Pa ra alguns autores, esta é a época em que se inicia a competição 
21.
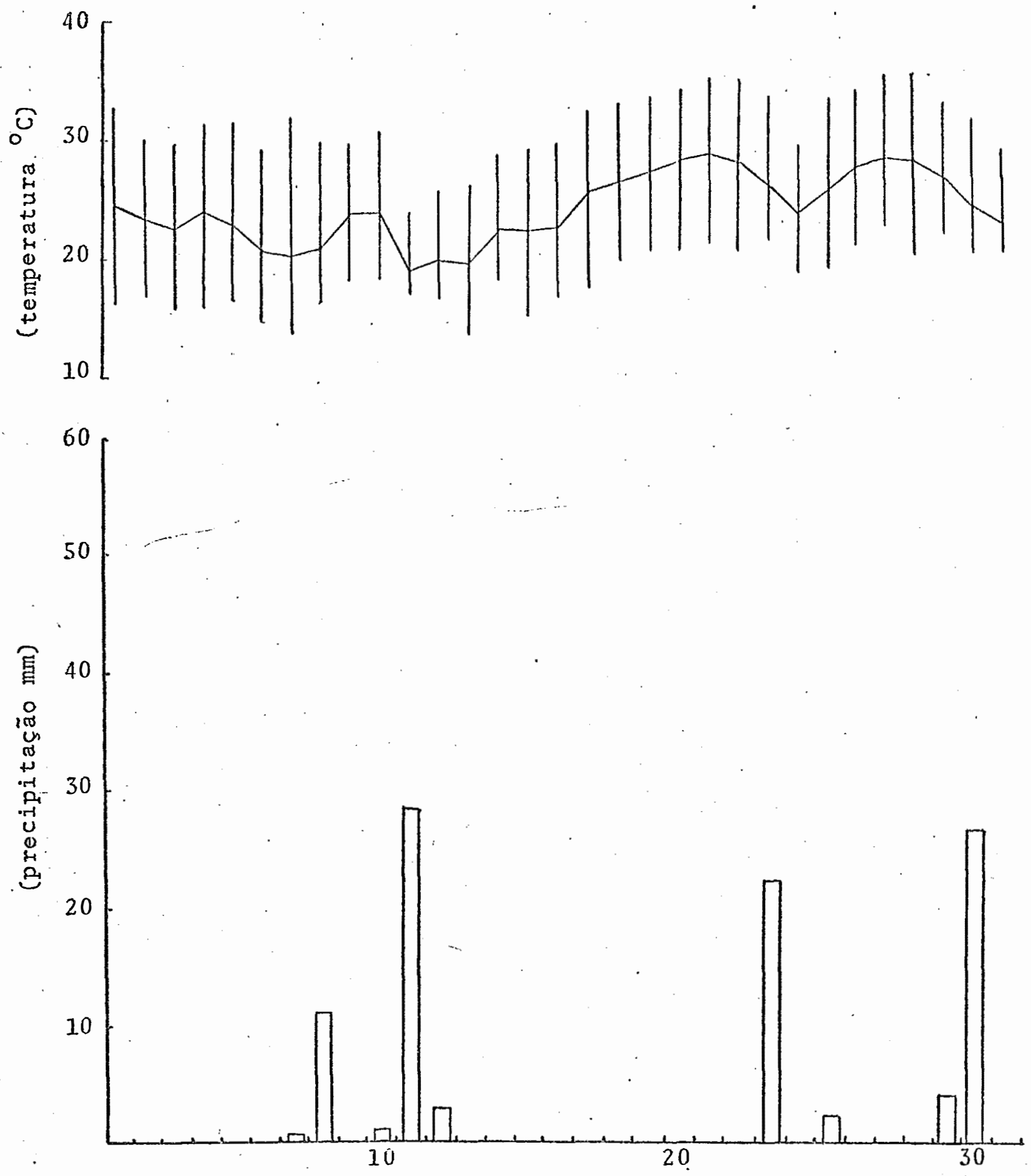

Figura 01 - Amplitude das variações térmicas (linhas ver ticais), temperaturas mëdias diārias ( linha contínua e precipitações diărias (barras ver ticais), ocorridas no mês de outubro de 1980 na FCAV/UNESP, Jaboticabal. Temperatura mé dia mensal de $24,0^{\circ} \mathrm{C}$ e precipitação total do Mès $99,3 \mathrm{~mm}$. 
22
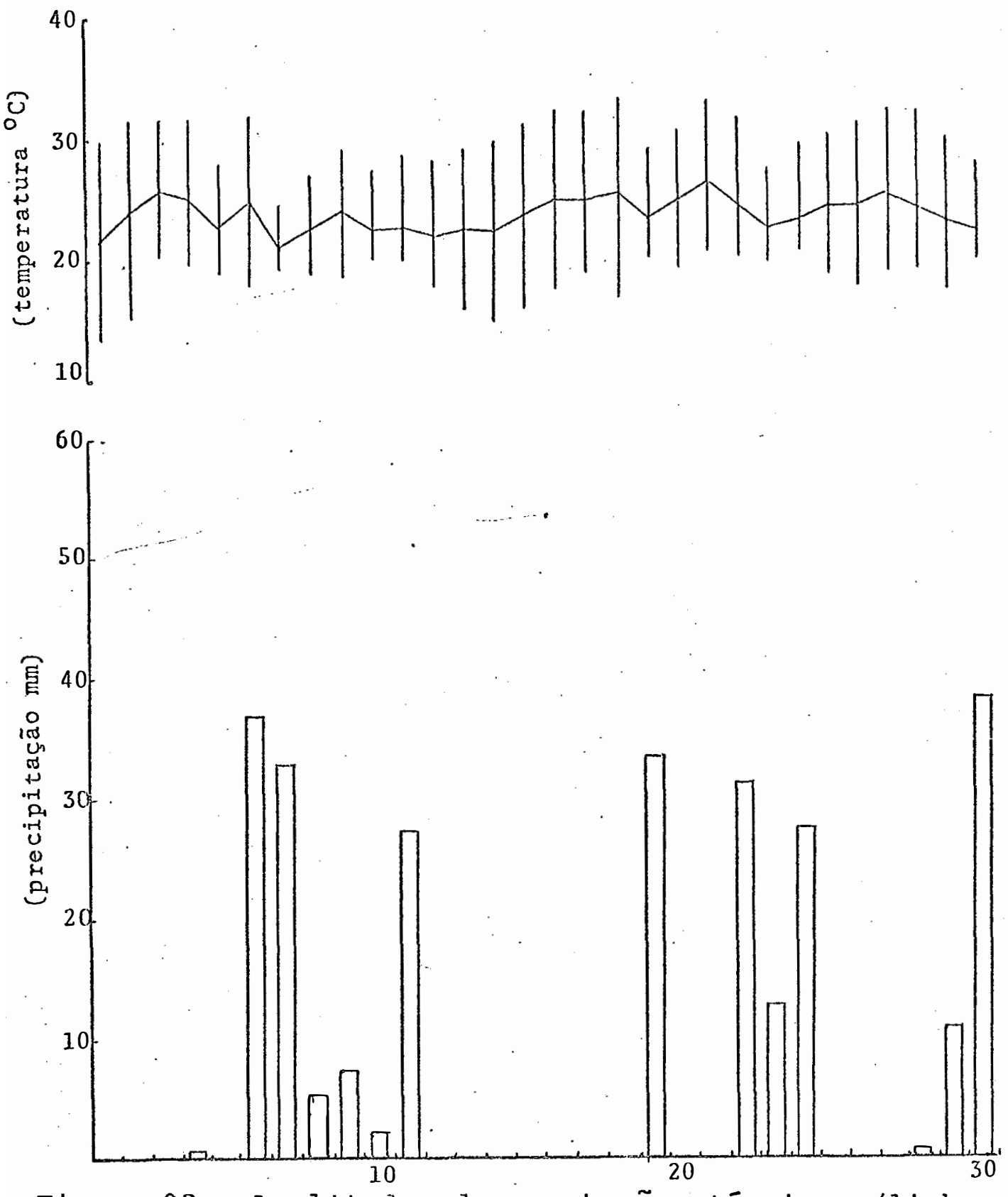

-Figura 02 - Amplitude das variações térmicas (linhas ver ticais), temperaturas médias diárias (linha contínua) e precipitações diărias (barras ver ticais), ocorridas no mês de novembro de 1980 na FCAV/UNESP, Jaboticabal. Temperatura média mensal de $23,7^{\circ} \mathrm{C}$ e precipitação total do mes $267,9 \mathrm{~mm}$. 
23
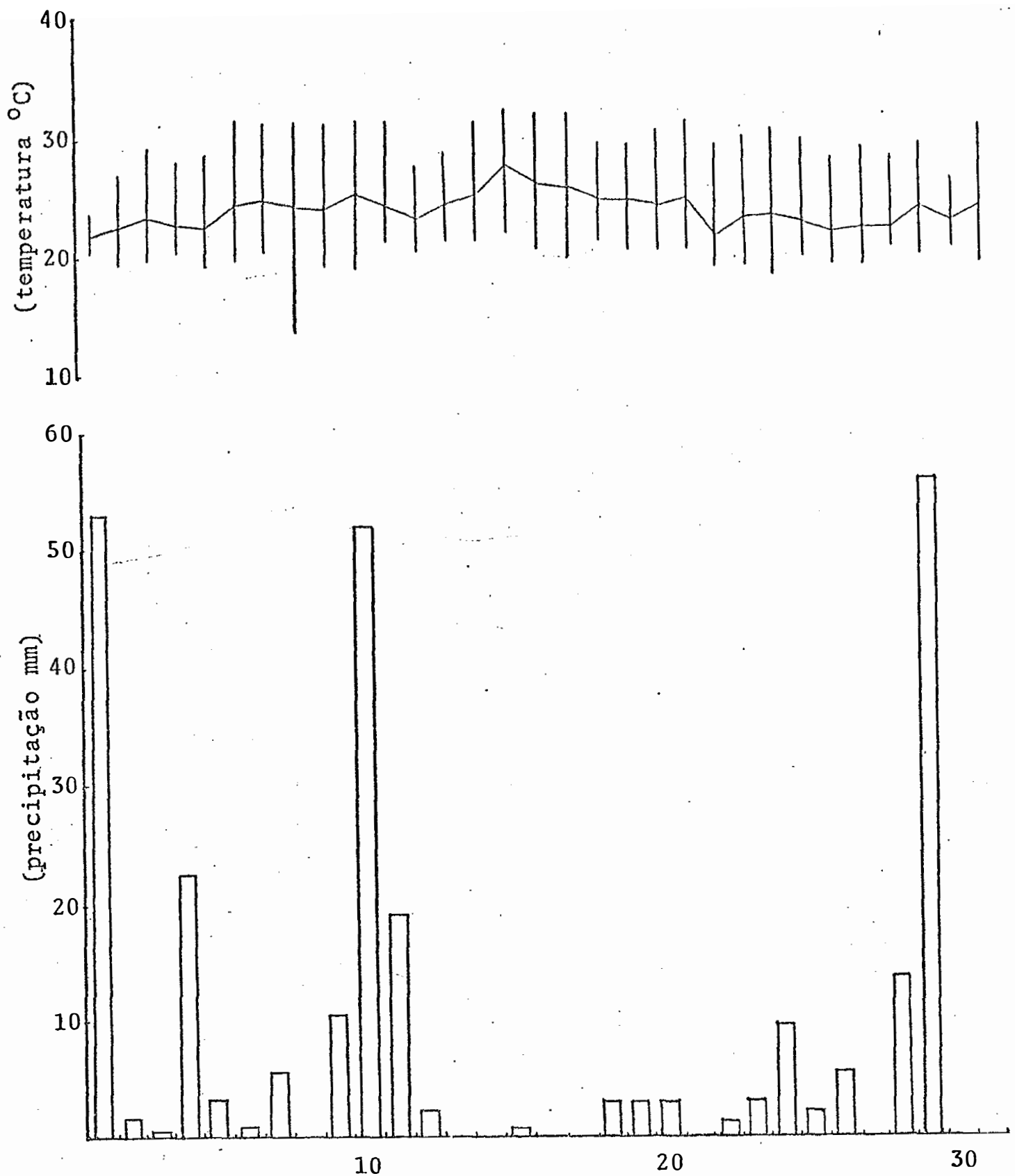

Figura 03 - Amplitude das variações tërmicas (linhas ver ticais), temperaturas mēdias diárias ( linhas continua) e precipitações diárias (barras ver ticais), ocorridas no mês de dezembro de 1980 na FCAV/UNESP, Jaboticabal. Temperatura mëdia mensal de $23,8^{\circ} \mathrm{C}$ e precipitação total do mës $270,6 \mathrm{~mm}$. 

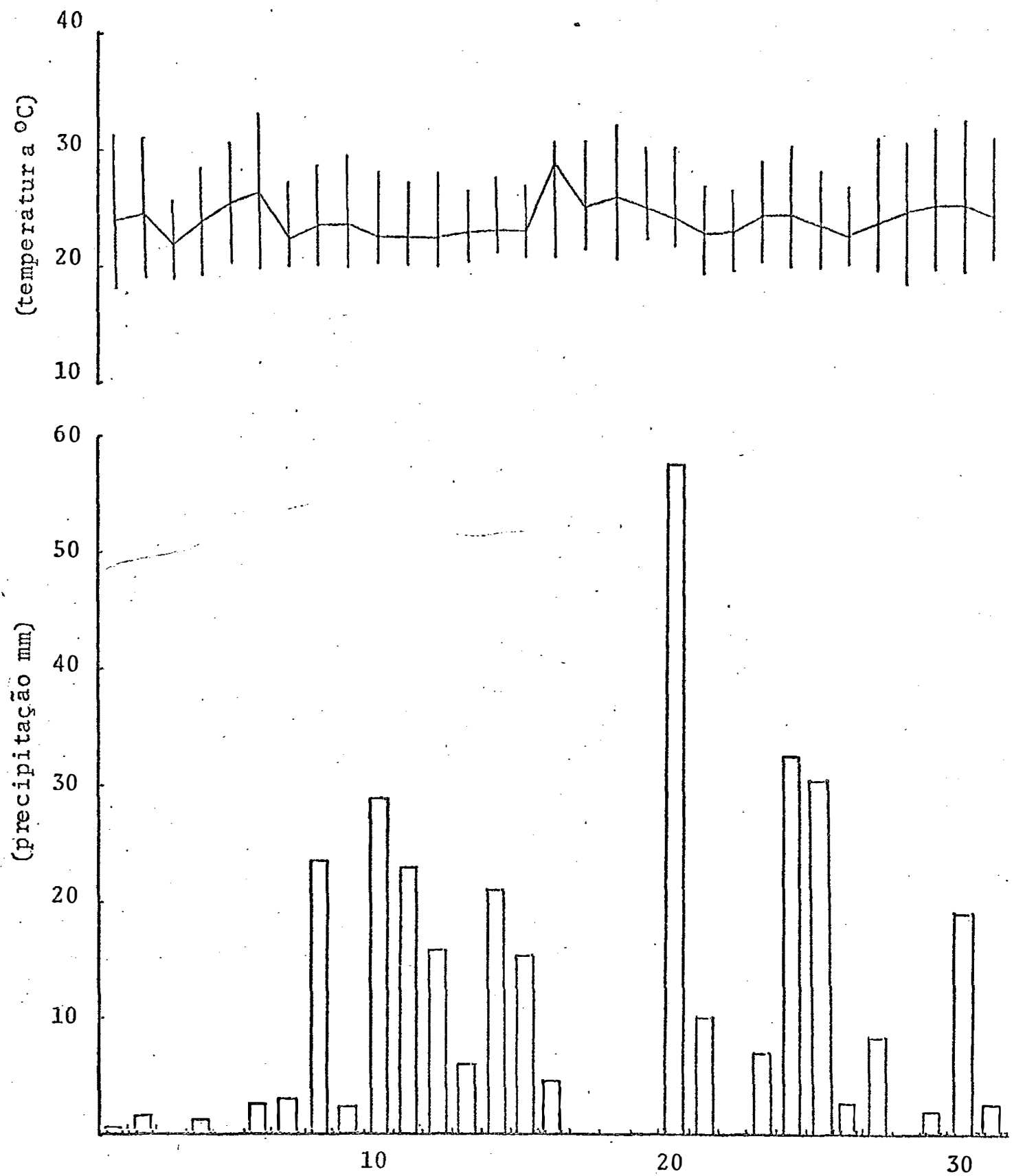

Figura 04 - Amplitude das variaçōes térmicas (1inhas ver ticais), temperaturas médias diărias (linha contínua) e precipitações diárias. (barras verticais), ocorridas no mês de janeiro de 1981, na FCAV/UNESP, Jaboticabal. Temperatura média mensal $23,8^{\circ} \mathrm{C}$ e precipitação total do mês $324,4 \mathrm{~mm}$. 

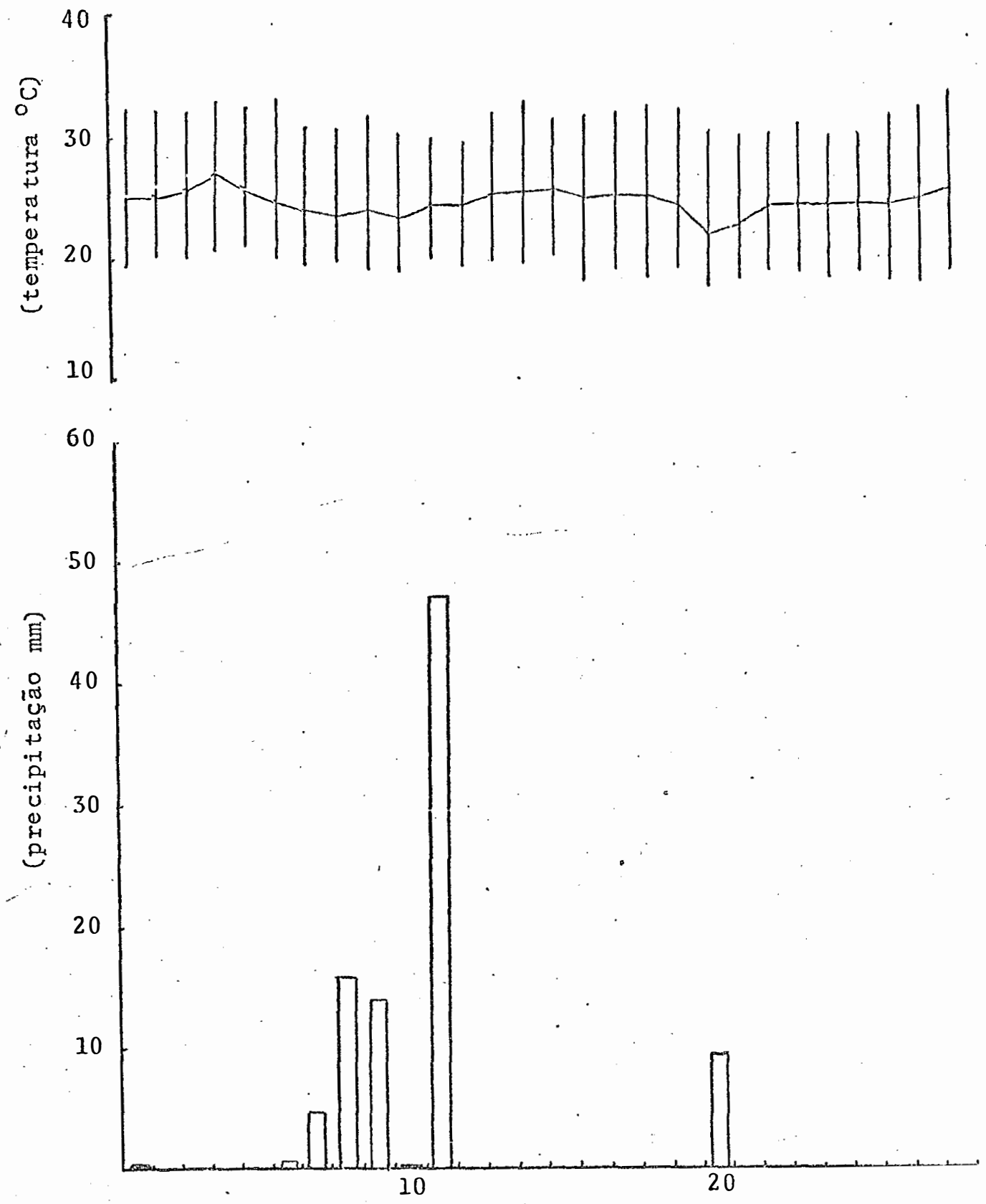

Figura 05 - Amplitude das variações térmicas (linhas vêr ticais), temperaturas médias diárias (linha continua) e precipitações diārias (barras verticais), ocorridas no mēs de fevereiro de 1981 na FCAV/UNESP, Jaboticabal. Temperatura média mensal $24,6^{\circ} \mathrm{C}$ e precipitação total do mês $90,9 \mathrm{~mm}$. 
mais intensa entre a cultura e a comunidade infestante (YAMAGIS HI et alii, 1978 e SWAIN et alii, 1975). Além destas, ocorreram com moderada frequência Brachiaria plantaginea (Link.) Hitch, Cassia tora I. e sida spp..

O material coletado foi levado ao laboratôrio, onde foi lavado para análise de micronutrientes, seco em estufa de circulação forçada de ar e, posteriormente, moỉdo e analizado quimicamente segundo metodologias descritas por SARRUGE \& HAAG (1974)。

Por ocasião do intenso florescimento do arroz, no vamente coletou-se material para análise química. Nesta ocasião, procurou-se fazer uma análise quantitativa da retirada de nu trientes, pois segundo os autores supracitados, é a época de in tensa competição entre a cultura e a comunidade infestante. Para tanto, coletou-se a superfície correspondente a um metro de linha de arroz, na área útil de cada parcela. Utilizaram-se de retângulos de madeiras de $0,60 \times 1,00 \mathrm{~m}$ ou de $0,40 \times 1,00 \mathrm{~m}$, os quais eram ajustados no sentido longitudinal da linha de semeadura, a qual foi mantida no centro do retấngulo. Posteriormente, coletou -se toda parte aérea acumulada pelas plantas emergidas na área abran gida pelo retângulo. Separou-se a comunidade infestante das plan tas de arroz. O material foi levado ao laboratório e processado e analisado de maneira semelhante à coleta anteriòr.

objetivando verificar os efeitos dos diferentes tratamentos sobre os teores de nutrientes no produto final, ou. seja, o arroz beneficiado, procedeu-se a colheita da cultura em 
23 de fevereiro de 1981. O beneficiamento foi realizado em equi pamentos próprios para beneficiar pequenas quantidádes e que são utilizados pelos compradores deste cereal, para averiguação da qualidade das diferentes partidás de arroz. Após ser benefí ciado, o arroz foi processado e analisado de maneira semelhante aos materiais anteriores.

Os resultados foram inicialmente submetidos à análise de variância pelo teste $\mathrm{F}$ e posteriormente foi procedido o desdobramento dos graus de liberdade para separação dos efeí tos do espaçamento, das doses de fertilização nitrogenada, da condição de manejo da comunidade infestante, e das interações entre estes efeitos. Quando houve efeitos das diferentes doses de nitrogênio, estudaram-se as regressões polinomiais entre o parâa metro em estudo e a dose aplicada. Esțe mesmo tipo de análise foi realizado no desdobramento de interações entre doses de ni trogênio e espaçamentos ou condição de manejo. Entre alguns dos parâmetros avaliados realiżaram-se estudos de correlação linear. 
5. RESULTADOS E DISCUSSÃO

Em vários dos parâmetros estudados objetivaram-sedi ferenças significativas entre os blocos experimentais, justificando o delineamento experimental utilizado.

- Na Tabela 02 são apresentados resultados referen tes às anālises quỉmicas das. plantas de Digitaria sanguinalis, por ocasião do perfilhamento da cultura do arroz. Observa-se in cialmente que, com relação aos macronutrientes, o potássio encon trava-se em maiores teores, seguido do nitrogênio, depois magnê sio, cálcio e, posteriormente, o fósforo. Dos micronutrientes, ọ̣ servou-se que o ferro encontrava-se em maiores concentrações, se guido do manganês, zinco e, finalmente, o cobre. Estudos de re grẹsão linear, entre os teorès dos diferentes nutrientes mos 


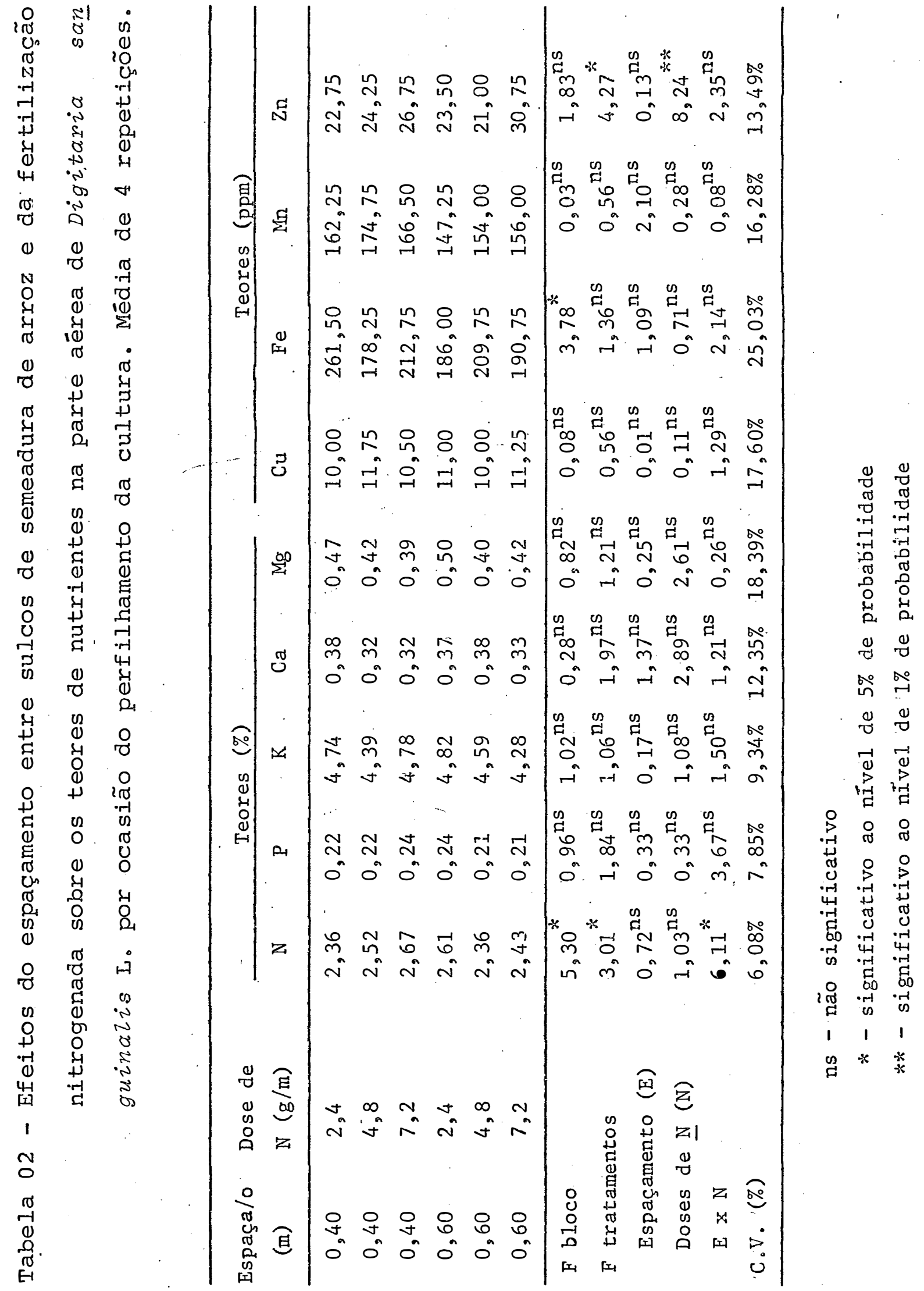


varam não haver relação significativa entre eles.

Pela análise da Tabela 02 pode-se observar que os diferentes tratamentos influenciàram significativamente os teores de nitrogênio e zinco; apenas. Com relação ao primeiro, observou-se efeitos da interação entre doses de nitrogênio e espaçamento. o desdobramento da interação mostrou efeitos significativos dos nỉveis de nitrogênio apenas no espaçamento de $0,40 \mathrm{~m} \quad(F=4,17 *)$ 。 Dentro deste espaçamento não houve correlação linear ou quadrati ca $\left(F=2,08^{\mathrm{ns}}\right.$ e $0,01^{\mathrm{ns}}$, respectivamente) entre os dois fatores. As diferenças puderam ser detectadas pelo teste de Tukey (dms= 0,28 ) onde observou-se que os teores do nitrogênio em $D$. sangui nalis nas parcelas que receberam $7,2 \mathrm{~g}$ de $\mathrm{N} / \mathrm{m}$ foram maiores que nas parcelas que receberam $2,4 \mathrm{~g}$ de $\mathrm{N} / \mathrm{m}$. Estes resultados indi cam que parte do nitrogênio fornecido à cultura foi absorvido pe las plantas daninhas, confirmando as observações de NODA (1977), LONG \& ALKAMPER (1978), OKAFOR (1973) e OKAFOR \& DE DATTA (1976). Com relação ao efeito do nitrogênio apenas no es paçamento de 0,40 m, supõe-se que seją devido a uma maior distrí buição deste na área, aliado ao fato de maior quantidade por uni dade de superfície de solo.

Os teores de zinco na planta foram influenciados pela aplicação do fertilizante nitrogenado. Observou-se correla ção linear significativa entre dose de $\mathrm{N}$ e os teores de zinco na planta ( $F=5,64 *$ contra $2,60^{\mathrm{ns}}$ para a regressão quadrática), in dicando que houve uma tendência de maior acúmulo de zinco à medi da que se aumentou a dose de $\mathrm{N}$ em cobertura. 
Digitaria sanguinalis é considerada por HoLM. et alii (1977) uma das principais cas plantas daninhas do mundo, sendo relatada em 56 paỉses como problemática em 33 culturas Cí tam-na como problemática às culturas de sequeiro, sendo observa da infestando a cultura de arroz na India. No Brasil, è conside rada por BLANCO (1975) como uma espécie muito abundante e alta mente nociva aos cultivos agrỉcolas, citando-a como uma das im portantes invasoras de arroz.

$\mathrm{Na}$ Tabela 03 apresentaram-se os resultados referen tes às análises quỉmicas das plantas de Indigofera hirsuta L。 por ocasião do perfilhamento da cultura. Observa-se que, dentre os macronutrientes, os teores de potássio foram equivalentes aos de nitrogênio na matéria seca. Os teores de cálcio foram supe riores aos do magnésio, os quais equivaleram aos de fôsforo. Observam-se várias diferenças entre os teores destes macronutrien tes nas duas espēcies daninhas estudadas. Inicialmente, a ordem decrescente de concentrações não è semelhante. Alēm da Indigofe ra hirsuta apresentar similaridades nos teores de $\underline{\mathrm{N}}$ e $\underline{\mathrm{K}}$ e de PeMg, o que não aconteceu com a gramỉnea, houve uma inversão na sequência decrescente dos teores com relação ao cálcio e ao mag nésio. Quantó aos micronutrientes, a sequência foi seme lhante à da Digitaria sanguinalis.

De uma maneira geral, a gramínea apresentou teo res mais elevados de potássio, magnésio, cobre, ferro e manganês quando comparada com a leguminosa. Esta, por sua vez, apresentou maiores teores de nitrogênio, e cálcio. Os teores de fósforo de 


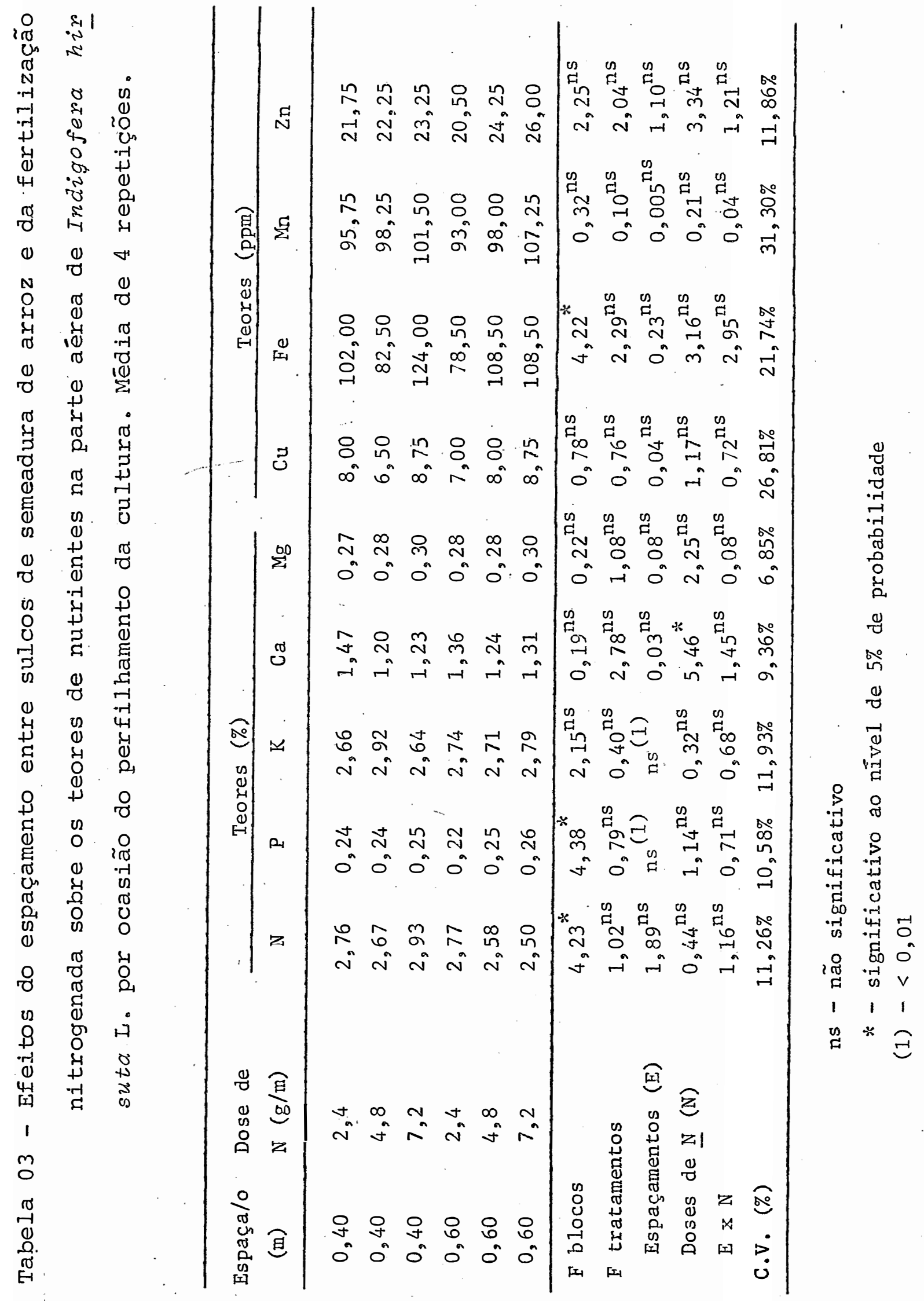


zinco foram equivalentes em ambas espëcies. Assim, por unidade de matéria seca acumulada, pode-se considerar que as espécies va riam com relação à capacidade de competir pelos diferentes nu trientes. Por exemplo, os teores de cálcio em $I$, hirsuta foram, em média, 3,7 vezes superiores aos verificados em $D$. sanguina Zis。

Os teores de cálcio na leguminosa foram alterados significativamente pela fertilização nitrogenada embora não se tenha encontrado qualquer corselação significativa entre estes parâmetros $\left(F=2,72^{\mathrm{ns}}\right.$ e $2,74^{\mathrm{ns}}$ para as regressões linear e qua drätica, respectivamente). Novamente, as diferenças foram detec tadas pelo teste de Tukey $(\mathrm{dms}=0,16)$, indicando maiores teores de cálcio para o mais baixo nỉvel de aplicação de nitrogênio. quando comparado com a dose de $4,8 \mathrm{~g}$ de $\mathrm{N} / \mathrm{m}$.

Com relação aos teores dos diferentes nutrientes na planta, não foi encontrada qualquer correlação significativa entre eles。

Os resultados das análises, quando comparadas com a bibliografia brasileira referente à composição química de al gumas espécies daninhas, ressaltam, em maior grau, as grandes diferenças existentes entre os teores dos nutrientes, verifica dos nos diversos componentes da comunidade infestante. Por exem plo, em Euphorbia heterophyzza L., SILVA (1977) observou teores de călcio $(3,29 \%)$ mais elevados que os do nitrogênio $(2,40 \%)$ na matéria seca da parte área. Resultados similares foram obtidos por GALLO et alii (1958) com Amaranthus tristis L. Os mesmos au 
tores ainda verificaram em folhas de Portulaca oleracea L., teo res de potássio 3,3 vezes superiores aos verificados em Euphor bia heterophyzza, vegetando no mesmo local.

CICERELLI et alii.(1977); abservaram em Indigofera hirsuta teores de $\mathrm{N}_{\circ} \mathrm{P}, \mathrm{K}$ e Mg da ordem de 2,06\%, 0,14\%, 1,26\% e 0,35\% na matēria seca. Estes teores, com exceção do magnésio, são in feriores aos teores ora verificados. Acredita-se que esta dife rença deva-se, em parte, às diferenças na idade da planta por ocasião da coleta da análise química. No trabalho citado, as plantas foram colhidas numa fase mais avançada de seu ciclo de desenvolvimento.

Na Tabela 04 são apresentados os resultados refe rentes às análises químicas da matéria seca da parte aérea das plantas de arroz por ocasião do perfilhamento. Tanto nas parce las mantidas no limpo, como naquelas que foram submetidas à com petição, a sequência decrescente dos teores foi a mesma. o potás sio encontrava-se em maiores teôres, seguido do nitrogênio, fós foro, cálcio e, posteriormente, o magnésio. Dentre os micronu trientes observaram-se maiores teores de manganês, depois ferro, zinco e, finalmente cobre.

As sequências verificadas para as plantas dani nhas divergem bastante da verificada para o arroz. Naquelas, o fósforo sempre encontrou-se no último lugar da sequência, enquan to que na cultura seus teores são mais elevados que os do cálcio e do magnésio. Com relação aos micronutrientes, o arroz apresen tou teores mais elevados de manganês, enquanto que as plantas 


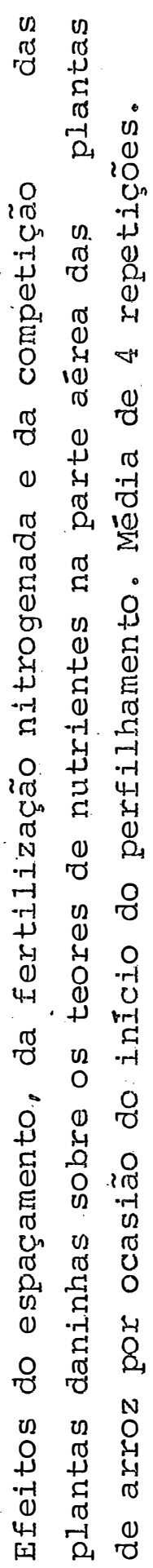

1

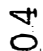

ro

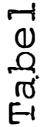

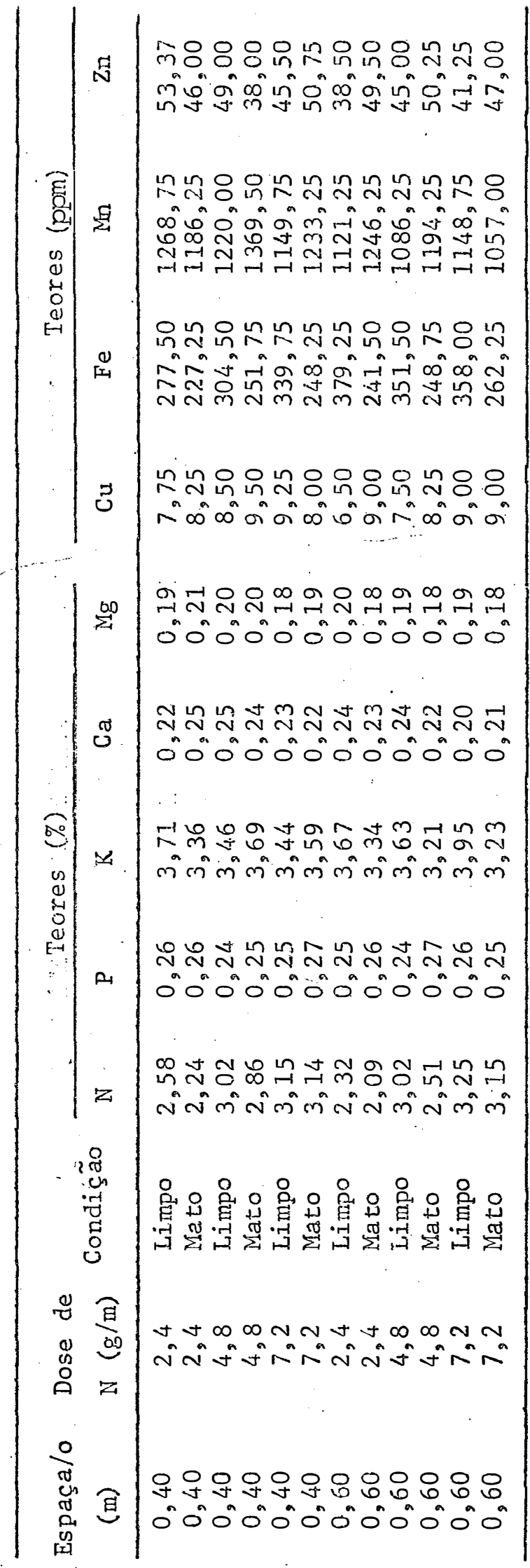

1

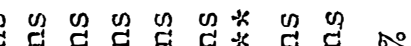

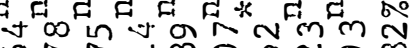

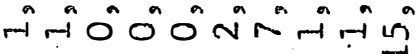

* ก Ñ Nं

\%

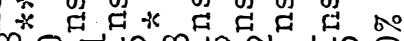
ง 0 ส ํำ

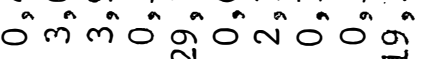

os us es en en en os

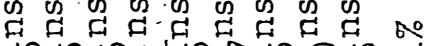
in in 0 की O

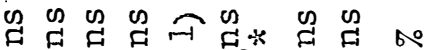

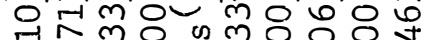
N

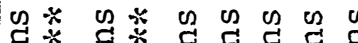

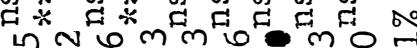

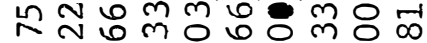

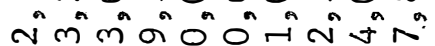

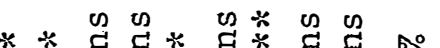
* N. ํำ

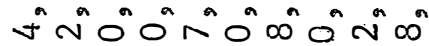

の

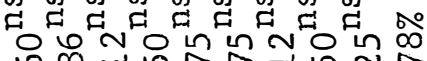

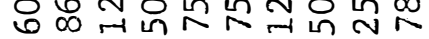

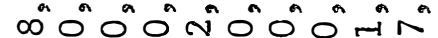

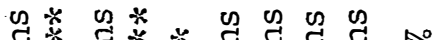
in $\sigma N N^{*}$ in $\infty$ a $\rightarrow \infty$ in $m$ in $\infty \infty m$ o

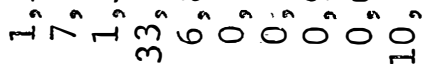

\section{뙤}

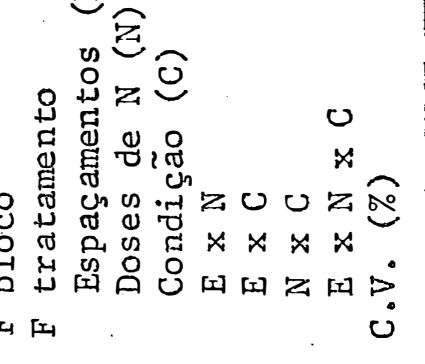

ชั ชั

$\pi$

ind $\cdot r-1$

.4 .

तั

ำ

مि

ชิ चี

ํํํำ

용

ए

rad

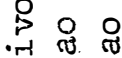

出

का 0

in 4 .

4 स

岳

an : in ${ }^{\text {rt }}$

म

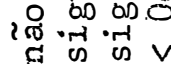

1111

出 $*$ 菏 
daninhas apresentaram teores mais elevados de ferro.

Quando desenvolveu-se no limpo, os teores de ni trogênio, fósforo, ferro, manganês e zinco, foram mais eleva dos no arroz que nas duas plantas daninhas, enquanto que os de cálcio e magnésio foram mais baixos. Os teores de potássio e co bre foram inferiores ao da $D$. sanguinalis e superiores aos da I. hirsuta. Na presença da competição das plantas daninhas esta ordem foi alterada apenas para o nitrogênio, cujo teor no arroz passou a ser intermediário entre $I$, hirsuta e D. sanguinalis.

Os teores de macronutrientes ora observados no ar roz são similares à aqueles observados por GARGANTINI \& BLANCO (1965) . Com relação aos teores apresentados por MEDEIROS \& MALA VOLTA (1980) abservaram-se diferenças marcantes no que se refere aos teores de manganês. Os teores observados pelos autores esti veram em torno de 50 ppm enquanto que no presente trabalho, os teores observados foram acima de $1000 \mathrm{ppm}$. No entanto, IRRI (sem data) e Seneviratne \& Mikkelsen (1961), citados por YOSHIDA (i 975 ) observaram teores de 1870 ppm e 789 ppm, respectivamente, em plantas de arroz de sequeiro vegetando em solo ácidos. Atrí. buem os autores o fato, à naior disponibilidade do elemento em solos de baixo pH. O solo em que foi desenvolvida a presente pesquisa é considerado ácido $(\mathrm{pH}=5,4)$.

Os teores de nitrogênio foram alterados significa tivamente pela fertilização nitrogenada, observando-se efeito li near entre as doses de nitrogênio e os teores do elemento na ma 
téria seca do arroz $\left(F=65,91^{* *}\right.$ contra $F=1,54^{\text {ns }}$ da regressão quadrática), o que era esperado, Objetivaram-se ainda efeitos da competiçāo das plantas daninhas, reduzindo significativamente os teores do elemento no arroz. Este efeito da competição ainda foi observado para os teores de potássio e de ferro na planta.

A fertilização nitrogenada tambēm alterou signifi catịvamente os teores de cálcio na matéria seca, seguindo-se uma tendēncia linear negativa $\left(F=10,67^{* *}\right)$ e quadrática $\left(F=8,00^{*}\right)$ indicando que com o aumento da fertilização nitrogenada, os teo res do cálcio na planta inicialmente diminuiram e, posteriormente, tenderam a aumentar. E possivel que o aumento do desenvolvi mento radicular do arroz com a fertilização nitrogenada tenha au mentado a captação do cálcio no solo. Eir doses maiores de nitro gênio houve um proporcionalmente maior desenvolvimento da parte aêrea e diluição do cálcio que tem baixa translocação na planṫa, aliado ao fato do solo apresentar baixos teores do elemento.

o espaçamento entré suj.cos de semeadura afetou significativamente apenas os teores de manganês na matéria seca Os teores erarn maiores nas plantas das parcelas no espaçamento de $0,40 \mathrm{~m}$. E interessante observar que neste espaçamento, as quantidades de fertilizantes adicionadas por unidade de superfí cie foraml, 5 vezes maiores que no espaçamento 0,60 m. Considerando que a fonte nitrogenada, o sulfato de amonio, é considerada aci dificante, pode-se supor um aumento na disponibilidade do micro elemento pelo decréscimo do $\mathrm{pH}$, na camada superficial do solo. 
Observou-se ainda efeito da interação entre espa çamento e competição das plantas daninhas sobre os teores de pô tássio, magnésio e zinco na matéria seca do arroz. Para o primeí ro e o último nutriente observou-se que a competição apenas al terou os teores em arroz no espaçamento de $0,60 \mathrm{~m}\left(\mathrm{~F}=4,31^{*} \mathrm{e}\right.$ $5,76^{*}$, respectivamente). Os teores do potássio foram diminuidos pela presença das plantas daninhas, indicando competição pelo elemento. No caso do zinco, o efeito foi inverso: os teores fo ram mais elevados nas parcelas com presença das plantas daninhas. E possivel que as plantas daninhas atuem na alteração da disponi bilidade de zinco no solo, ou ainda, forneçam material ôrganico passivvel de decomposição e fornecimento de zinco ã planta. culti vada. ROGER et alii (1939) já haviam observado que algumas plan tas daninhas apresentavam alta capacidade de acumular zinco mesmo em solos pobres no elemento e que um adequado manejo desta vege tação poderia ser utilizado para suprir deficiēncias das plantas cultivadas, principalmente o milho. De acordo com LINDSAY (1972), a disponibilidade do zinco no solo, depende, em parte, da presen Ça e quantidade de agentes quelatantes no solo, os quais podem ser exudados do sistema radicular de inúmeras espécies vegetais e da decomposição da matéria orgânica.

Com relạção ao magnésio, observou-se efeito do es paçamento dentro das parcelas mantidas em competição $\left(F=9,33^{* *}\right)$ sendo maiores os teores em plantas no espaçamento de 0,40 m. Tan to para este, como para os dois nutrientes acima, observa-se um maior efeito da comunidade infestante no espaçamento mais largo. 
Neste espaçamento é maior a ārea disponível à instalação e desen volvimento das plantas daninhas e há maior proporção de plantas daninhas por unidade de população ou de biomassa da planta culti vada.

Na Tabela 05 são apresentados resultados referen tes às análises quỉmicas da comunidade infestante por ocasião do florescimento da cultura do arroz. Dentre os macronutrientes, o potássio apresentou maiores teores, depois o nitrogênio, seguido do cálcio, magnésio e, finalmente, o fósforo. Com relação aos micronutrientes, a escala decrescente de teores foi ferro, man ganês, zinco e cobre. Observa-se, comparando com a amostragem anterior, que a sequência observada de macronutrientes foi seme lhante à da I. hirsuta e a sequência de micronutrientes, foi se melhante à ambas espécies daninhas. A comunidade apresentou teo res de ferro superiores aos observados para as duas espécies. Com relação ao nitrogênio, fósforo, potássio, cobre e zinco ocor reu o contrário: os teores na comunidade foram inferiores aos verificados para as plantas daninhas. Os teores de magnésio e manganês da comunidade foram inferiores aos da Digitaria e supe riores aos da Indigofera. Com o cálcio ocorreu o inverso.

Os teores de nitrogênio na comunidade infestante foram alterados significativamente pela aplicação do fertilizan te nitrogenado. Observou-se correlação linear entre a dose de ni trogênio aplicado e o teôr do mesmo na matéria seca da parte aérea das plantas daninhas. $\left(F=4,21 *\right.$ contra $F=0,09^{\mathrm{ns}}$ da re gressão quadrática), indicando que a comunidade infestante foi 


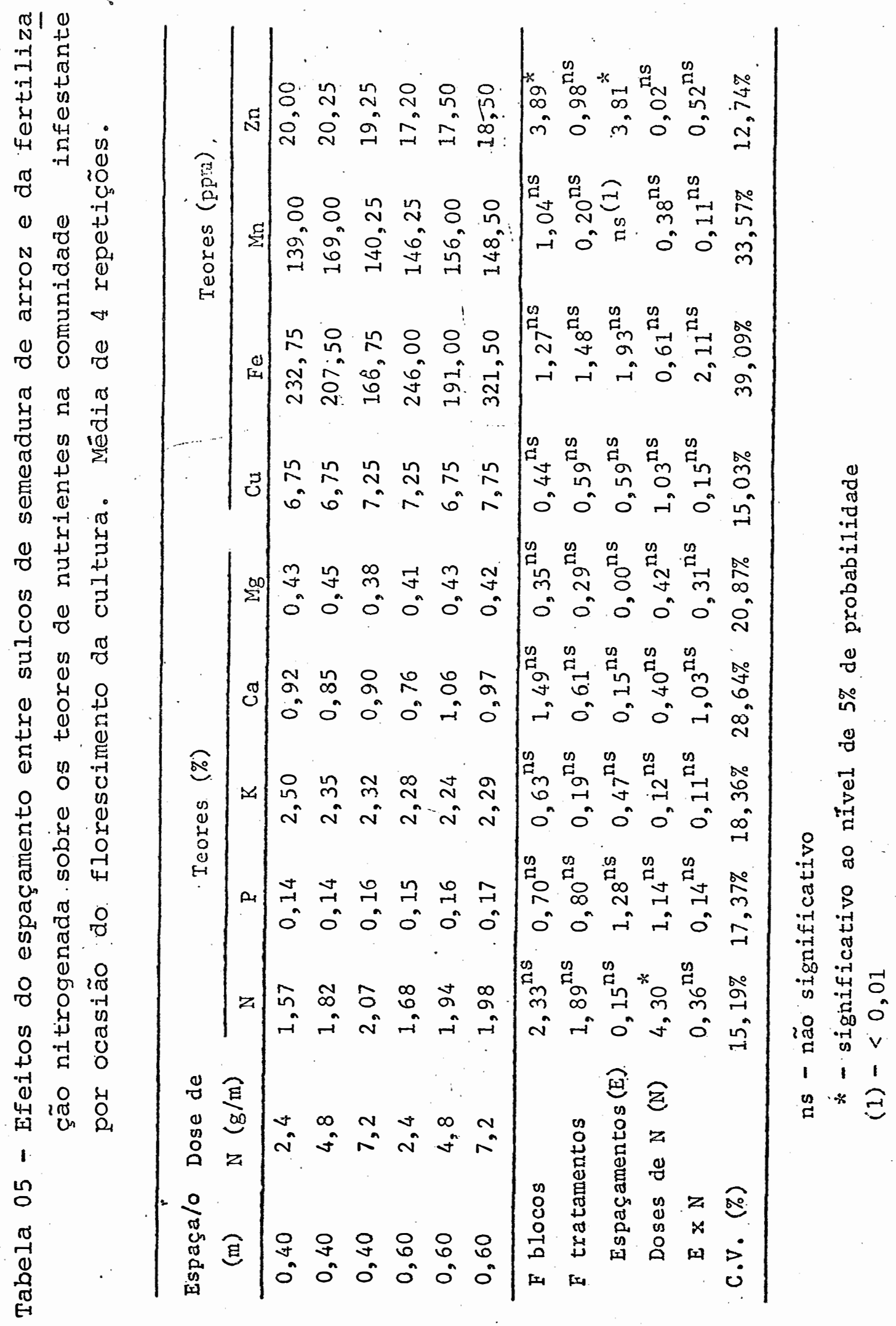


capaz de absorver parte do nitrogênio fornecido à cultura. Estas observações já haviam sido feitas por NODA (1977), LONG \& ALKAM PER (1978), OKAFOR (1973) e OKAFOR \& DE DATTA (1976). Acredita-se que para estes autores, esta absorção foi mais drástica, uma vez que trabalharam em arroz no sistema inundado, onde a aplica ção do fertilizante é em área total. No presente caso, a aplica ção foi realizada próxima à linha de plantio do arroz e apenas uma parcela da comunidade teve acesso à fertilização.e, mesmo assim, numa região em que a competição da cultura é intensa. EL -SHAFEY et alii (1975) observaram que aumentando-se a dose de $\mathrm{N}$ na adubação de plantio do milho, havia um efeito negativo so bre os teores do elemento na comunidade infestante. Admitem os autores que houve um efeito positivo do fertilizante no cresci mento da cultura, aumentando seu potencial competitivo. inte ressante observar que a adubação foi realizada no sulco de se meadura onde o acesso e utilização do fertilizante foi muito mais dirigido à planta cultivada.

Os teores de zinco na comunidade infestante foram alterados significativamente pelo espaçamento da cultura. No es paçamento de $0,40 \mathrm{~m}$ os teores eram maiores. E possivel que neste caso novamente uma maior quantidade de sulfato de amonio na área possa estar atuando no $\mathrm{pH}$ do solo e daí, sobre a disponibilidade do zinco.

Na Tabela 06 são apresentados resultados referen tes às análises químicas da matéria seca da parte aérea das plantas de arroz por ocasião do florescimento. A ordem decres 


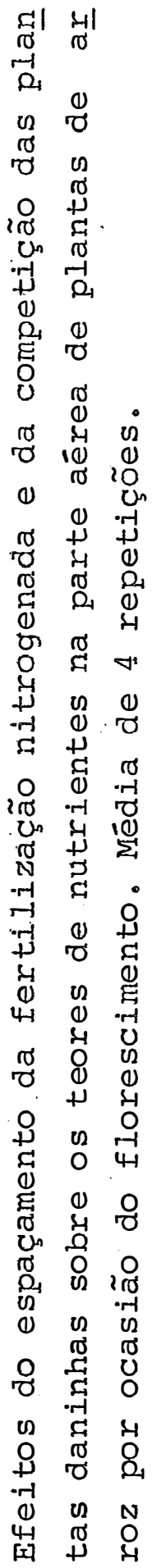

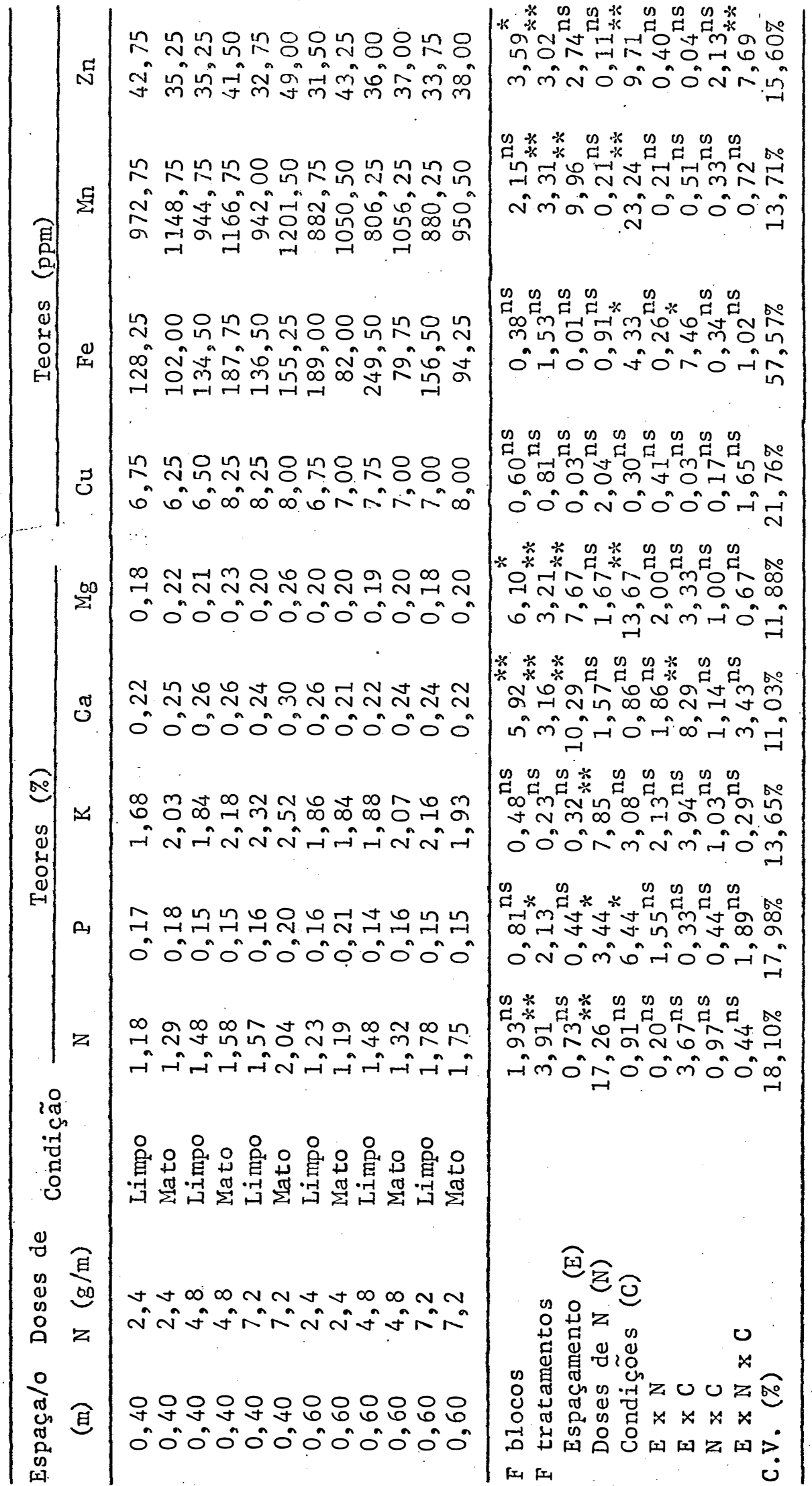

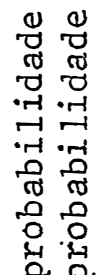
ชี ชั ํํำ จี ه 당 留

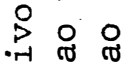
i ปึ? -ry - r t $\rightarrow$ $4+4$ 品. . $\begin{array}{lll}-1 & 4 \\ 0 & 4\end{array}$ क 崫 然. 111 咨* 0 
cente dos teores foi a mesma para parcelas mantidas no limpo e no mato. O potássio encontrava-se em maiores concentrações, se guiḍo do nitrogênio, depois o cálcio, o magnểsio e, posteriormen te o fósforo. A sequência decrescente nos teores de micronutrien tes foi manganês, ferro, zinco e cobre. As sequências são seme lhantes àquelas verificadas para a cultura no perfilhamento, se bem que os valores são menores. GARGANTINI \& BLANCO (1965), nes ta mesma fase do ciclo, observaram sequência semelhante. A se quência observada por MEDEIROS \& MALAVOLTA (1980) foi diferente, trabalhando com outra variedade e utilizando solução nutritiva como substrato para o desenvolvimento da planta.

Comparando-se os teores de nutrientes na comunida de infestante com os do arroz, observa-se que a primeira apresen tou maiores valores de nitrogênio, potăssio, cálcio, magnésio e ferro. O arroz mostrou maiores teores de fósforo, cobre, manga nês e zinco.

O espaçamento entre sulcos de semeadura do arroz, alterou significativamente os teores de cálcio, magnésio e man ganês na planta cultivada, sendo mais elevados no espaçamento de $0,40 \mathrm{~m}$. E interessante observar que com relação aos dois pri meiros elementos, a comunidade infestante apresentou teores bas tante mais elevados que o arroz. Num espaçamento de 0,40 m é me nor a participação das plantas daninhas em relação a cultura. Des ta maneira, a influência da comunidade infestante pode tornar-se menor, naqueles elementos que requer em maiores quantidades que a planta cultivada. 
No caso do manganês o efeito do espaçamento pode estar ligado à acidificação maior da camada superficial do solo conforme foi comentado anteriormente.

A presença das plantas daninhas afetou negativa mente os teores de ferro e positivamente os teores de fósforo, magnésio, manganês e zinco. No caso dó ferro é possível que a competição imposța pela comunidade infestante tenha determinado este comportamento. Observou-se, para este elemento um efeito de interação entre o espaçamento e a presença das plantas daninhas, que quando desdobrada, mostrou que a comunidade infestante ape nas influenciou os teores de Fe. no arroz quando no espaçamento de $0,60 \mathrm{~m}\left(\mathrm{~F}=11,58^{* *}\right)$, justamente onde a pressão competitiva desta comunidade deve ter sido maior.

Os teores de fósforo, magnésio, manganês e zinco foram influenciados positivamente pela presença das plantas dani nhas. Com relação ao zinco, este efeito jã havia sido observado no perfilhamento, sendo comentada a possível explicação. Obtendo -se a média dos teores de cada elemento no arroz no limpo e compa rando-se com os da cultura no mato, observam-se maiores teores nesta última situação, exceção feita ao ferro; que possivelmente tenha sofrida intensa competição uma vez que a comunidade infes tante foi bastante mais exigente no elemento que a planta culti vada. Estes teores maiores nas parcelas em competição com plantas dani nhas, provavelmente possam ser explicadospor um efeito de con . centração devido ao menor crescimento resultante da competição • Este efeitto foi mais drástico no mangânes, em que a cultura mos 
trou alta capacidade de acúmulo, quando os teores do arroz no mato foram cerca de 20\% superiores aos da cultura no limpo.

As doses crescentes de fertilização nitrogenada afetaram positivamente ede maneira linear os teores de nitrogê nio $\left(F=8,63^{* *}\right.$ contra $0,06^{\text {ns }}$ da regressão quadrática) e de potássio ( $F=3,78^{*}$ contra $0,08^{\text {ns }}$ da regressão quadrática) na maté ria seca da parte aérea das planta de arroz. Gumberg (1959), ci tado por EL-SHAFEY ét alii (1975), sugere que, após a nitrifica ção, o nitrato absorvido tem efeito promotor na absorção de po tássio.

Além destes elementos, a fertilização afetou nega tivamente os teores de fósforo, não sendo observada qualquer ten dência linear ou quadrática $\left(F=2,18^{\text {ns }}\right.$ e $0,71^{\text {ns }}$, respectivamen te). O teste de Tukey (dms $(5 \%)=0,26)$ mostrou que nas parcelas que receberam $2,4 \mathrm{~g}$ de $\mathrm{N} / \mathrm{m}$, os teores de fósforo no arroz foram superiores aos da parcela que receberam as doses maiores. $E$ pos sỉvel que nestas últimas tenha havido efeito de diluição pelo maior crescimento da planta, ou ainda que, a acidificação próxi ma do sistema radicular provocada pelo sulfato de amonio, possa ter alterado negativamente a disponibilidade do fósforo ao ar roz.

Observou-se ainda uma interação significativa dos efeitos do espaçamento e da presença das plantas daninhas sobre os teores do cálcio na matéria seca do arroz, mostrando que, quan do no mato, as plantas no espaçamento de $0,60 \mathrm{~m}$, apresentavam me nores teores dos elementos $\left(F=18,57^{* *}\right)$ quando comparadas com 0 
menor espaçamento. Tal fato não ocorreu, nas parcelas no limpo $\left(F=0,06^{\mathrm{ns}}\right)$. Estes resultados talvez se devam a possível menor capacidade competitiva do arroz no espaçamento mais largo, alia do ao fato de alta exigência do mato em relaçào ao cálcio.

Na. Tabela 07 são apresentados os resultados refe rentes aos acúmulos de matéria seca e de nutrientes pela parte aérea da comunidade infestante numa área de 1 hectare. Pode-se observar que nenhum dos tratamentos logrou alterar significativa mente os parâmetros estudados. Neste ponto é interessante consi derar a relativa estabilidade da comunidade, tanto em termos de recrutamento dos recursos do meio, como na menor susceptibili dade aos efeitos das alterações impostas no seu meio ambiente, quando comparada com populações puras.

De uma maneira geral,. as comunidades infestantes são constituídas de inúmeras populações as quais, por sua vez, apresentam-se em altas densidades. Com esse grande número de plantas vegetando na mesma área, o desenvolvimento de cada indi vỉduo é controlado, em maior grau, pelas restrições do meio do que pelo seu potencial genético. A grosso modo, pode-se afirmar que o desenvolvimento da comunidade infestante é proporcional às limitações do meio em recursos. Numa extensão do "Principio de Liebig": a biomassa desenvolvida por uma determinada comunidade infestante é proporcional ao recurso do meio que, em relação às necessidades gerais da comunidade, encontra-se em menores quanti dades. Assim quando do fornecimento de qualquer recurso essen cial ao desenvolvimento da comunidade, podem ocorrer duas situa 


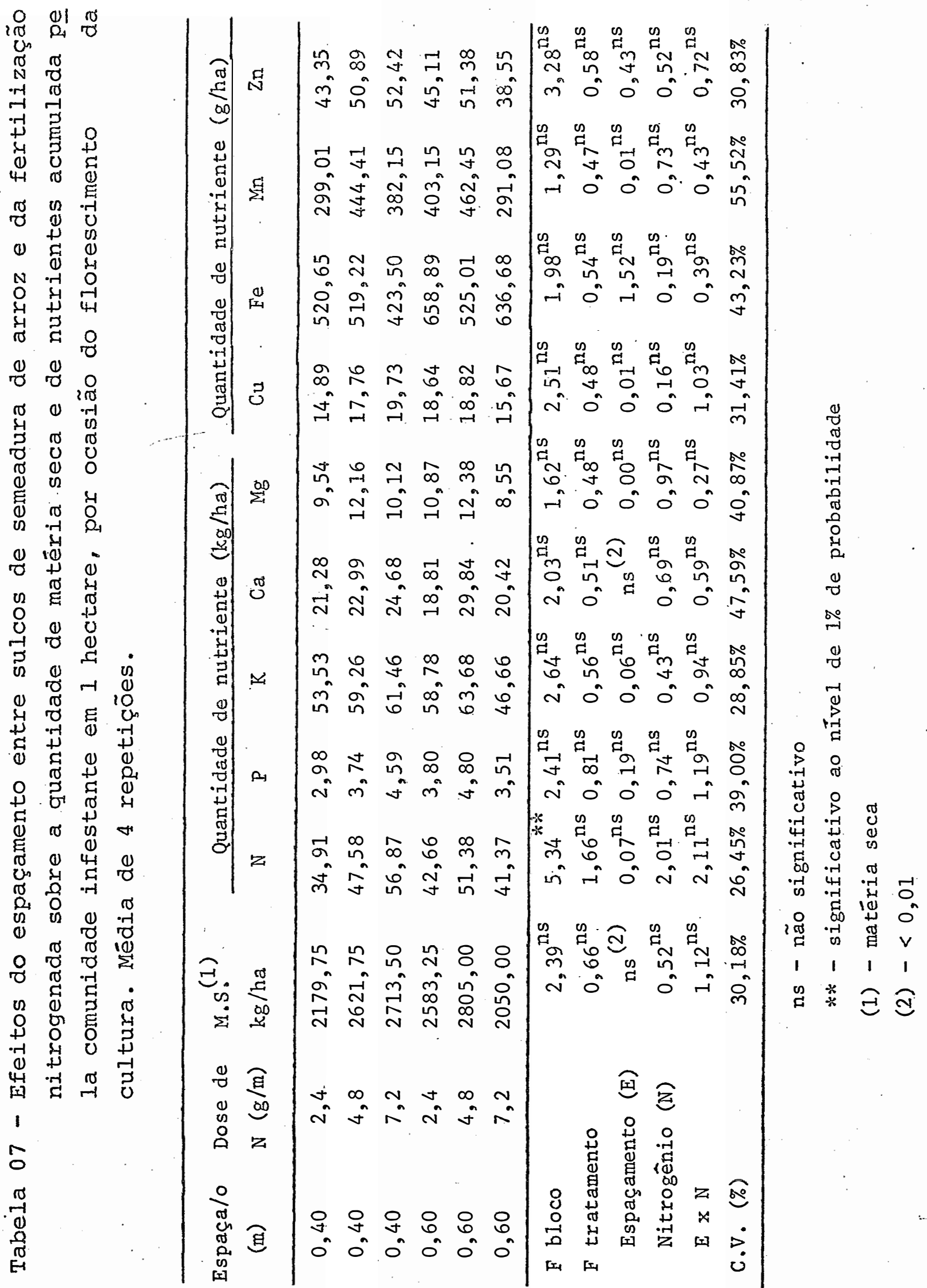


Ções. Em primeiro lugar, que o recurso fornecido seja aquele que esteja limitando o crescimento da comunidade. Neste caso, haverá um efeito benéfico ao desenvolvimento desta até que outro recur so passe a ser o fator limitante.

$\mathrm{Na}$ segunda situaçăo, o recurso fornecido não è o elemento limitante do desenvolvimento da comunidade. Neste ca so, algumas populações que apresentarem maiores capacidades de resposta ao recurso adicionado, deverão ter seus. crescimentos bastante favorecidos e com isso poderão apresentar maiores taxa de recrutamento dos recursos não adicionados em detrimento da quelas espécies que apresentaram pouca ou nenhuma resposta ao recurso fornecido. Estas últimas terão seus desenvolvimentos bas tante prejudicados. Assim, nesta segunda situação, observa -se que o efeito do fornecimento do recursso não favoreceu o desen volvimento da comunidade que continua sendo controlado pelo fa tor limitante, mas alterou:a participação das diferentes espécies no total de biomassa seca acumulada. E possível que esta seja a explicação para a falta de resposta à fertilização nitrogenada mostrada pela comunidade infestante, uma vez que os teores foram alterados significativamente.

Com relação ao efeito do espaçamento é interes sante considerar que a cultura e a comunidade infestante inicia ram o desenvolvimento na mesma época. Esta última, apresentando um crescimento inicial mais intenso, foi capaz de competir efí cientemente mesmo no espaçamento menor. Mesmo assim, é verídico que no espaçamento menor o sombreamento por parte do arroz foi 
maior. No entanto, nesta intensidade, a importância do sombrea mento talvez ainda tenha ficado aquém do fator ecológico limitan te ao desenvolvimento da comunidade infestante.

Na Tabela 08 são apresentados os resultados refe rentes aos acúmulos por hectare de matéria seca e de nutrientes pela parte aérẹ da cultura do arroz por ocasião do florescimen to.

o acúmulo de matéria seca foi significativamente maior no espaçamento de 0,40 m. Considerando apenas as parcelas no limpo, o acúmulo de matéria seca foi em torno de 18 \% maior neste espaçamento. No entanto, como a densidade de semeadura foi mantidas, o número de indivíduos na mesma área foi 33\% maior. Isto indica que no menor espaçamento pode ter havido competição intraespecifica.

Observaram-se também efeitos da competição imposta pelas plantas daninhas reduzindo o acúmulo de matéria seca pela cultura em torno de $40 \%$. Além disso, houve interação dos efeitos do espaçamento e da presença das plantas daninhas. Observou -se que o efeito do espaçamento de 0,40 m, promovendo um maior acúmu lo de matéria seca de arroz por hectare, apenas foi verificado nas parcelas no limpo $\left(F=12,46^{* *}\right)$. Na presença das plantas da ninhas este efeito näo foi significativo $\left(F=0,08^{\mathrm{ns}}\right)$ devido principalmente aos efeitos da competição.

o acúmulo de matēria seca pela cultura foi alte rado de maneira linear pelas doses de nitrogênio aplicados $\left(\dot{F}-11,30^{* *}\right.$ contra $1,25^{\text {ns }}$ da regressão quadrática). No 


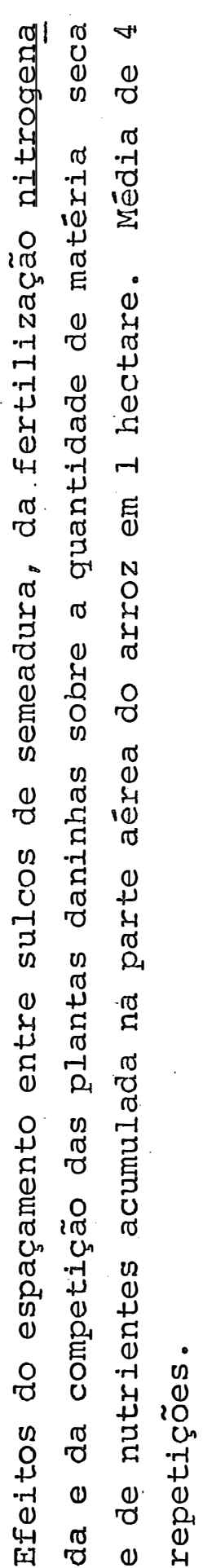

$\infty$

告

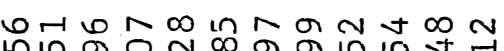
a 이 0 ด

$\infty \mathrm{No}$ o in $m$ in mo

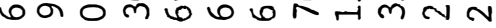

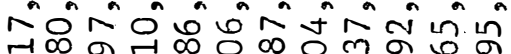
성 m N

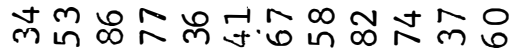

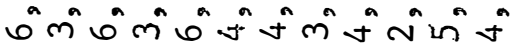

$N \infty$ N $\mathrm{N}+i \mathrm{i}$ - $\mathrm{N}+\infty$

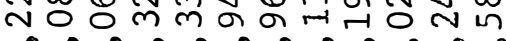

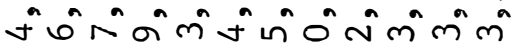

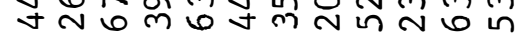

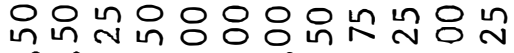

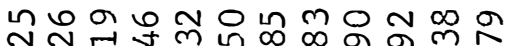
m"n $m^{n} 0$ $\infty$ 건 $m-1 \infty N$ a 0 a $N$ b กี่

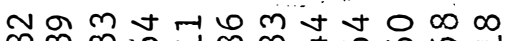

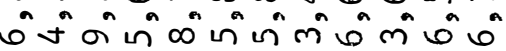

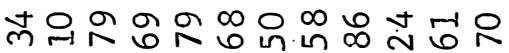
$\infty^{n}$ nं ปั ขं

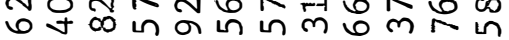

웅

200

un

वृ

o

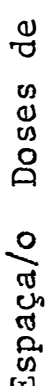

z

崩 回

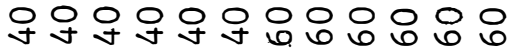

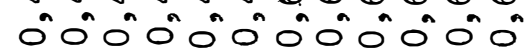
$\infty$ 으

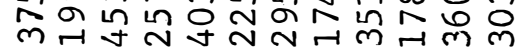

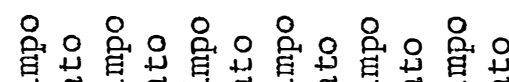

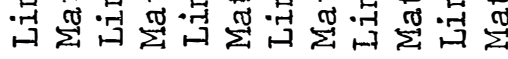

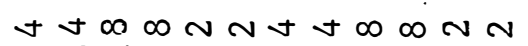

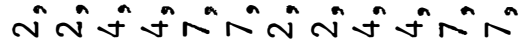

$\mid$

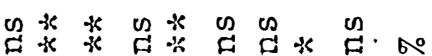
다 0060 制

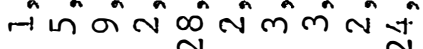
U艹

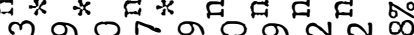

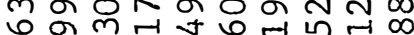

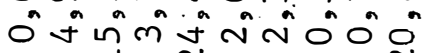

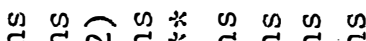

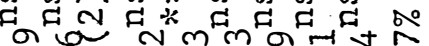

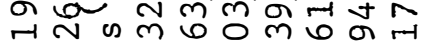
on ${ }^{a}$ म

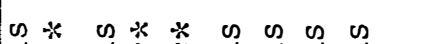
I* $* * *$ E के तु वे न

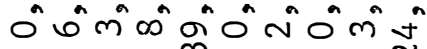
范获 in

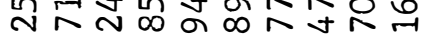
नं नं

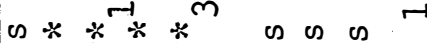

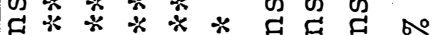
$0^{*} \infty \infty^{*}$ in $n^{*}$ in ${ }^{4} m$ in

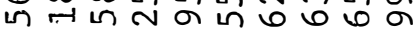

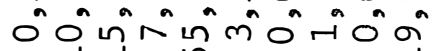

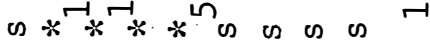
ت****** * ต

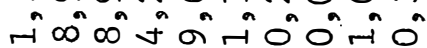

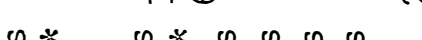

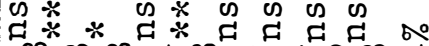
$\infty m \infty \pm \infty \pm$

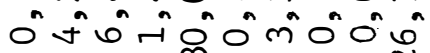
获 $\sim m \sim \sim N \sim N$

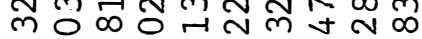

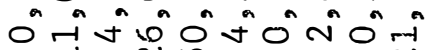
u $*$ r $* \mathrm{~N}^{\mathrm{n}}$ un us $N$ 苨

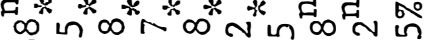
m คก กั |xl 1
هั ه

$\pi$

त्र

$\rightarrow-4$

तิ กิ

مـ

i. 용

م

चु

ํํำ

هั ชั

더다

$\stackrel{8}{>}$

덤대

구요

ชึ? तकी 0 . U

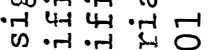

象

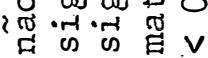

$\begin{array}{lllll}1 & 1 & 1\end{array}$

品 
espaçamento mais largo observou-se uma correlação linear ( $F=$ $6,89^{*}$ contra $0,34^{\text {ns }}$ de regnessão quadrática) entre as doese de $\underline{N}$ e a matéria seca acumulada na cultura. No menor espaçamento não foi possível observar tendência linear ou quadrática $(F=0,54$ ns e $2,91^{\text {ns }}$, respectivamente), indicando que a competição intraespe cífica, talvez por luz, pode ter limitado o maior desenvolvimento da cultura que seria promovido pelo nitrogênio. Em reforço a este comentário, observa-se, que em média no espaçamento de 0,40 $\mathrm{m}$, do menor nîvel de nitrogênio aplicado ao maior, houve um in cremento na matéria seca do arroz da ordem de 9\%. No espaçamento de $0,60 \mathrm{~m}$, este incremento foi de $41 \%$

Observaram-se ainda efeitos do espaçamento com rela Ção às quantidades de nitrogênio, fósforo, potássio, cálcio, mag nésio, manganês e zinco acumulados pela cultura do arroz. Em to dos estes elementos as quantidades foram maiores nas parcelas se meadas $0,40 \mathrm{~m}$; de distāncia entre sulcos de semeadura. Consideran do que o acủmulo de matéria foi 13\% maior, observou-se que, com exceção do nitrogênio que foi similar os diferentes nutrientes fo ram acumulados numa proporção levemente superior ao da matéria seca, com destaque para aqueles cujo espaçamento menor alterou positivamente os seus teores na planta, como é o caso do cálcio, do magnésio e do manganês. Por exemplo, a quantidade de $\underline{M n}$ foi em torno de $22 \%$ maior no espaçamento de 0,40 m. No caso do ferro, quando no lim po, houve efeitos significativos do espaçamento sobre o seu teor na matérịa seca do arroz (Tabela 06). Talvez este fato tenha contribuido para explicar o comportamento do elemento na presen 
te tabela.

A competição imposta pelas plantas daninhas afe tou negativamente a quantidade acumulada de todos os elementos estudados.

A fertilização nitrogenada alterou positiva e li nearmente as quantidades acumuladas de nitrogênio, potássio, cál cio, magnésio e cobre, pelas plantas de arroz em um hectare (F= $51,81^{* *}, 28,36^{* *}, 12,62^{* *}, 16,28^{* *}$ e $15,74^{* *}$ contra os valores de $0,24^{\mathrm{ns}}, 0,12^{\mathrm{ns}}, 1,91^{\mathrm{ns}}, 1,43^{\mathrm{ns}}$ e $0,65^{\mathrm{ns}}$, respectivamente) . Os teores de fósforo haviam sido negativamente afetados pela fertí lização nitrogenada (Tabela 06), o que deve ter contribuído para anular o efeito do maior acúmulo de biomassa.

Observaram-se ainda efeitos da interação entre es paçamento e doses de nitrogênio sobre as quantidades do prôprio elemento e do cálcio acumulados em um hectare. Com ambos os nu trientes, nos dois espaçamentos houve efeito linear significati vo $\left(F=7,66^{*}\right.$ e $10,62^{* *}$, para o nitrogēnio e $F=4,41^{*}$ e $8,56^{* *}$ para o cálcio, para os espaçamentos de 0,40 e $0,60 \mathrm{~m}$, respectiva mente) entre as doses de $\underline{N}$ e a quantidade dos nutrientes acumulados. As quantidades de magnésio e zinco acumuladas tạ bém foram significativamente alteradas pela interação $\mathrm{N}$ x C. Em ambos os nutrientes não se observou qualquer tendência linear ou quadrática entre as doses de $\mathrm{N}$ e as quantidades acumuladas pela cultura do arroz em um hectare, quando desenvolvida no limpo $\left(F=1,74^{\mathrm{ns}}\right.$ e $2,94^{\mathrm{ns}}$ para $\circ$ cálcio e $F=0,01^{\mathrm{ns}}$ e $3,21^{\mathrm{ns}}$ para $\cdots$ zinco). No entanto, quando a cultura desenvolveu-se no mato, ob 
servaram-se tendências lineares $\left(F=7,38^{*}\right.$ contra $0,27^{\text {ns }}$ da regres são quadrätica, para o cálcio e $F=9,25^{* *}$ contra $0,77^{\text {ns }}$ de re gressão quadrática para o zinco). Este comportamento parece in dicar que a fertilização nitrogenada incrementou a capacidade da cultura competir pelo cálcio e zinco do solo.

Não se observou qualquer correlação linear signi ficativa entre as quantidades de nutrientes absorvidas pela comu nidade infestante (Tabela 07) e os teores (Tabela.06) ou quanti dades destes elementos absorvidos pela cultura do arroz. Este fato é um indicativo de que os teores de nutrientes e as quanti dades absorvidas por cada competidor, näo dependem exclusivamente da taxa de recrutamento do outro.

Partindo-se do princípio de que nos dois espaça mentos, as populações por hectare eram diferentes e consideran do-se que no sulco de semeadura a densidade de sementes foi cons tante, procurou-se estudar os efeitos dos diferentes tratamen tos sobre o acúmulo de matéria séca e de nutrientes no arroz por unidade de linha de semeadura. Os resultados estão apresentados na Tabela 09 .

Observa-se que a matéria seca acumulada foi em torno de $23 \%$ menor no espaçamento de $0,40 \mathrm{~m}$, novamente eviden ciando uma possível competição intraespecífica no menor espaça mento. A redução do acúmulo de matéria seca devida à presença das plantas daninhas foi ao redor de $40 \%$. E interessante obser var que este valor é similar ao verificado por hectare, indican do que a taxa de influẽncia da comunidade infestante independeu 


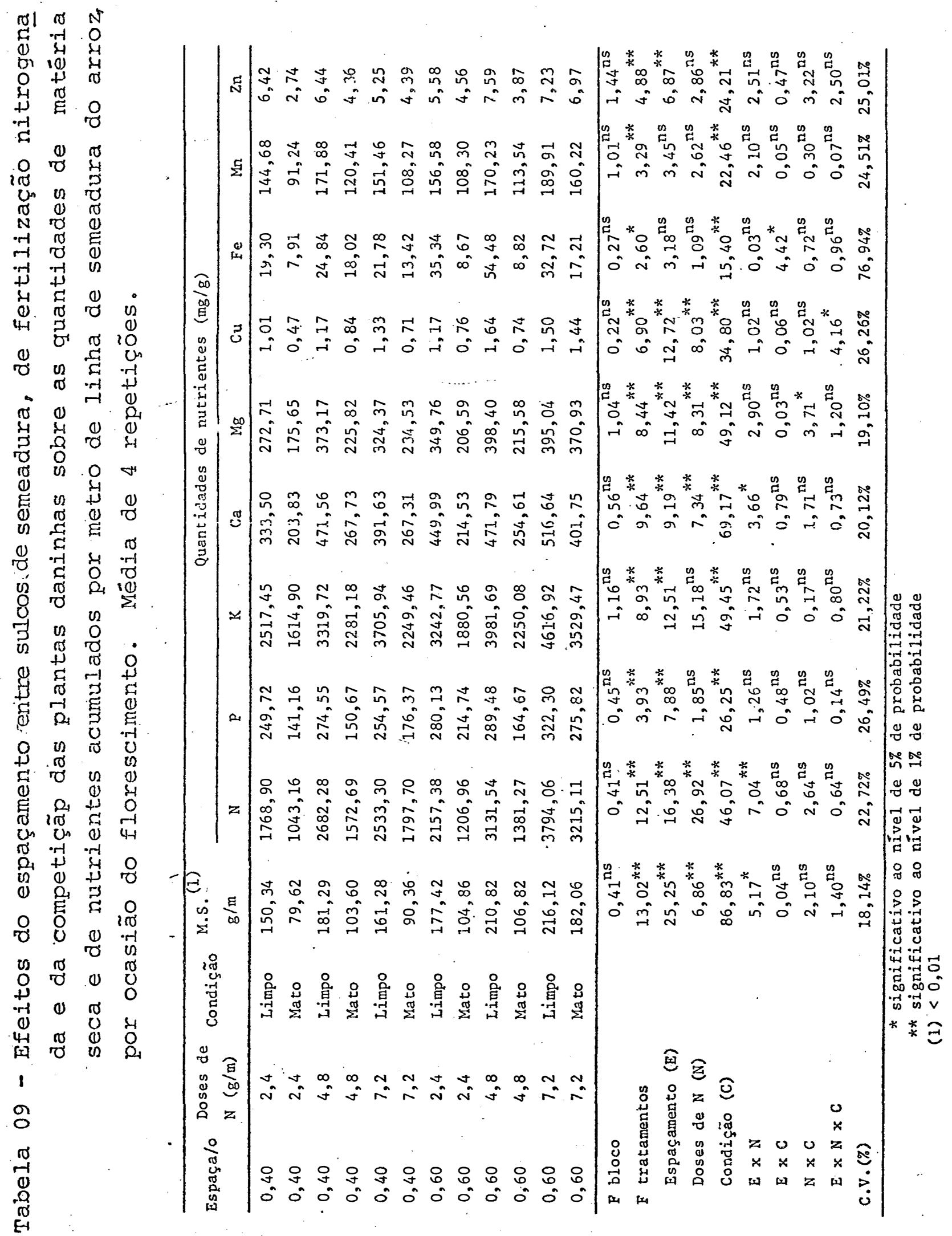


da densidade populacional do arroz. Provavelmente, isto ocorreu devido ao fato de que a comuniciade infestante e a cultura prati camente iniciaram o desenvolvimento ao mesmo tempo; e a prime ra, devido a sua maior taxa de crescimento inicial, anulou, em parte, os efeitos do espaçamento. E interessante que em futuros experimentos deste tipo permita-se o desenvolvimento da cultura no limpo por um determinado perỉodo, que não seja longo sufí ciente para abranger o período total da competição.

As doses crescentes de nitrogênio aplicados em cobertura influenciaram de maneira linear a matéria seca do arroz por unidade de linha de semeadura $\left(F=13,30^{*}\right.$ contra $0,41^{\text {ns }}$ para a regressão quadrática) indicando que a cultura respondeu ã fertilização nitrogenada proporcionalmente à dose aplicada. No entanto, desdobrando-se. a, interação E x N pode-șe observar que o efeito do nitrogênio foi significativo ape nas no espaçamento de 0,60 m. Supõe-se que o menor espaçamento, a competição intraespecífica tenha sido limitante à resposta ao nitrogênio. No espaçamento de $0,60 \mathrm{~m}$, o efeito do $\underline{\mathrm{N}}$ foi li near ( $F=5,32^{*}$ contra $0,10^{\text {ns }}$ da regressão quadrática). Com exceção do ferro e manganês, a quantidade $\underline{\text { a }}$ cumulada de todos os outros nutrientes por unidade de linha de semeadura foi maior no espaçamento de 0,60 m. Os efeitos positi vas do menor espaçamento sobre os teores de manganês na planta (Tabela 06) foram suficientes para anular, em parte, o efeito do maior acúmulo de matéria seca. A quantidade acumulada de ferro foi menor no espaçamento de $0,40 \mathrm{~m}$, no entanto a falta de signi 
ficância neste caso, como no da quantidade acumulada por hecta re, pode ser atribuído aos altos coeficientes de variação obser vados 。

A presença das plantas daninhas reduziu sensivel mente as quantidades acumuladas de todos os nutrientes, por uni dade de linha de semeadura de arroz.

Com relaçăo às doses de nitrogênio, basicamente o comportamento foi similar ao verificado por hectare uma vez que, para cada total, no desdobramento, uma certa porcentagem de - parcela foi dividida por um fator (1/25000 no espaçamento de $0,40 \mathrm{~m}$ ) e outra porcentagem idëntica dividida por outro fator $(1 / 16666,67$ no espaçamento de 0,60 m). Desta maneira, as rela ções foram mantidas.

Os teores de nitrogênio e de cálcio foram afeta dos significativamente pela interaçăo $\mathrm{E} \times \mathrm{N}$. Nos dois espaçamen tos, houve efeito linear das doses de nitrogënio $\left(F=4,65^{*}\right.$ e $\mathrm{F}=26,83^{*}$ contra $3,11^{\mathrm{ns}}$ e $0,47^{\mathrm{ns}}$ para as regressões quadrāticas, nos espaçamentos de 0,40 e 0,60 m,respectivamente). Em outro tí po de desdobramento da interação, observa-se que, à exemplo do ocorrido para a matéria seca $\left(F=30,18^{* *}\right)$, tanto para o nitro gênio como para o cálcio, o espaçamento alterou significaticamen te a quantidade acumulada por metro de linha, apenas no maior nível de nitrogēnio aplicado. Isto indica que nos dois níveis mais baixos de nitrogênio, em ambos espaçamentos, a resposta da planta foi similar. No entanto, quando aplicaram 7,2 g de. N/m no esṕaçamento de $0,40 \mathrm{~m}$, a competição intraespecífica limitou a 
resposta da planta em maior grau que no espaçamento de $0,60 \mathrm{~m}$. As quantidades de nitrogênio e de cálcio acumulados por metro de linha de arroz, nas parcelas que receberam o maior nível de $\underline{\mathrm{N}}$ fo ram em torno de 38 a $28 \%$ menores nas parcelas com espaçamento de $0,40 \mathrm{~m}$ quando comparada com $0,60 \mathrm{~m}$.

Na Tabela 10 apresentam-se os dados referentes às quantidades por hectare de matéria seca e de nutrientes acumula dos pelo conjunto cultura mais comunidade infestante, que dora vante será chamado de sistema.

A quantidade de matéria seca acumulada pelo sistema foi afetada positivamente pelo espaçamento de $0,40 \mathrm{~m}$ quando comparado com o de $0,60 \mathrm{~m}$. O incremento foi em torno de 13\%, maior mantendo-se a mesma proporção verificada para a quantidade acumulada apenas pela cultura (Tabela 08). Este fato foi possî vel porque a matéria seca acumulada pela vegetação infestante não foi influenciada pelo espaçamento. o espaçamento ainda alte rou positivamente as quantidades de potâssio, manganës e zinco acumulados no sistema.

A presença da comunidade infestante alterou posi tivamente as quantidades de matéria seca e de nitrogênio, fósfô ro, potássio, cálcio, magnésio e cobre acumulados pelo sistema. Comparando parcelas no limpo com aquelas no mato, a quantidade de matéria seca acụmulada foi em torno de $21 \%$ menor. Dentre os nutrientes cujas quantidades foram alteradas positivamente pela presença das plantas daninhas, deve-se destacar o cálcio e mạ nésio que as parcelas no limpo apresentavam em torno de 68\% e 


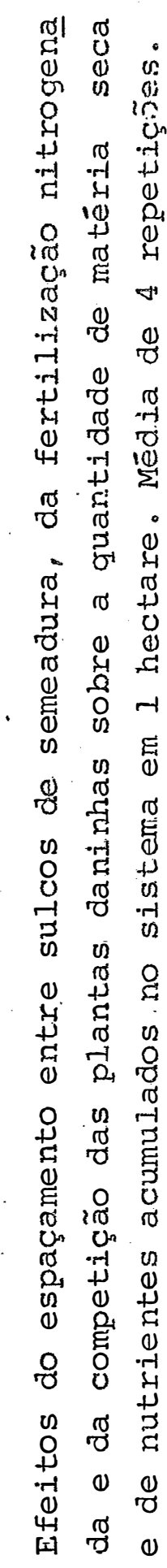

O

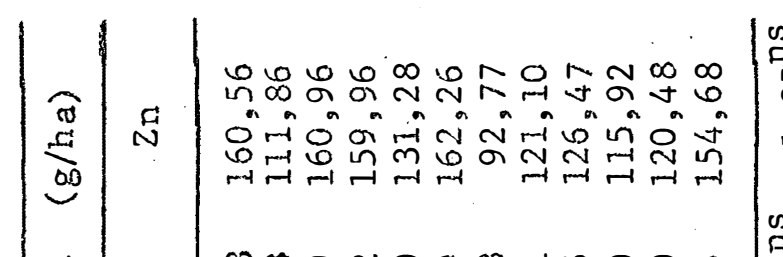

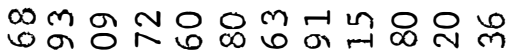
岳

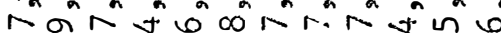

거숭 $10 \infty \infty$

min

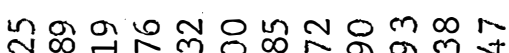

mon

$\infty \mathrm{m} N$ U

+र

mov n NaOm Na 6 in

mNำ

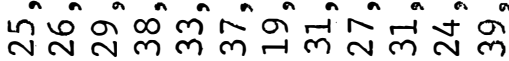

Ntmorl $m m+\infty \infty m$

$\infty$ न m $\infty$ न व $\infty$ m 6 \% थn

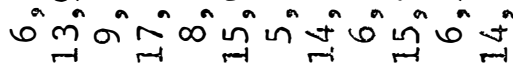

trama o

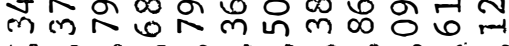

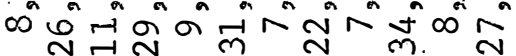

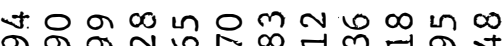

ทั่

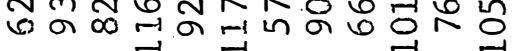

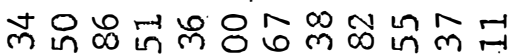

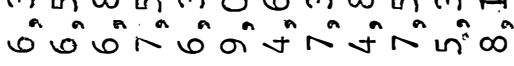

As

중ㅇㅇㅇำ

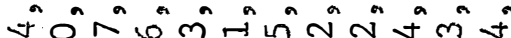

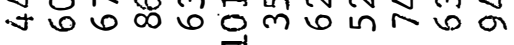

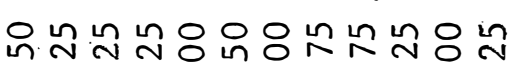

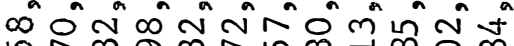

जी

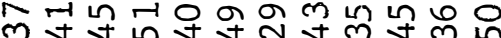

! 요

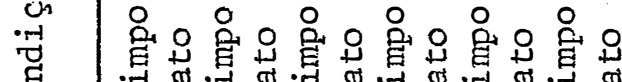

ن

$\stackrel{\otimes}{\circlearrowleft}$

o

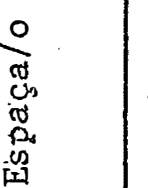

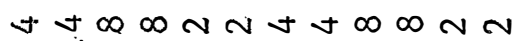

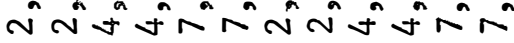

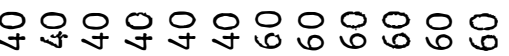

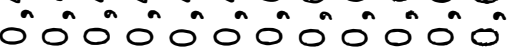

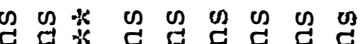

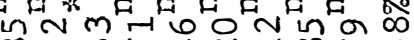
$\infty$ or $m$ M rino 0 กิ

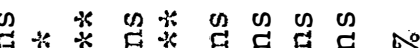

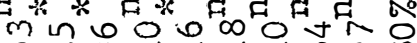

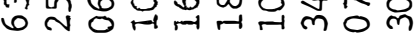

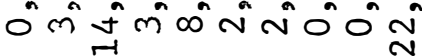

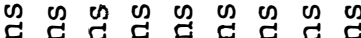
시 $m$ ป⿻

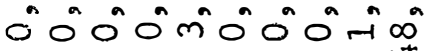

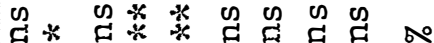
min Nmin

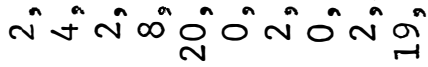

o

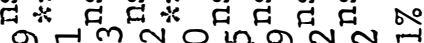
बำ 그

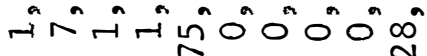

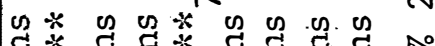

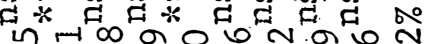
ஸून ศல் m艹 约 $\rightarrow 6$ in in $\infty$ O 0 ก 0

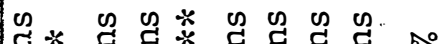
“** $\left.{ }^{*}\right)^{*}$

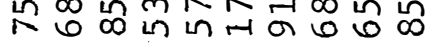

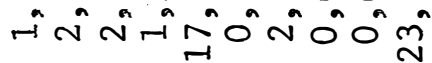

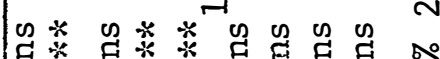

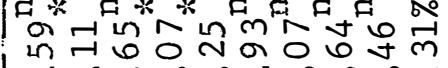

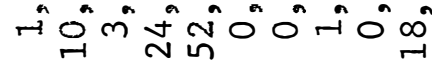
*** *

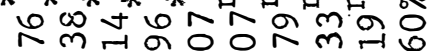

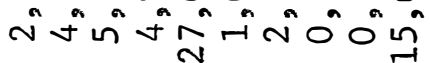

\section{ब्ञ્己 \\ 串品 \\ 出 \\ व

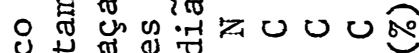

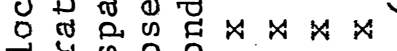 H in 0 的原}

ชี ซี

त

$\cdot-r-r$

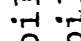

तิ त्रิ

ㅇํㅇ

范

ฮै 웜

ํํำ ํำ

वै क्ष

덩 히 rid

$\$$

- $\begin{array}{lll}0 & 0 & 0 \\ 3 & 0 & 0\end{array}$

o 8 it.-1 - -1 我 $\pi 0$ $200 \cdot+1 \cdot \pi)$ $\cdot r$ 计 4 क. 1 200 .

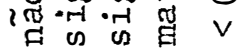
$\begin{array}{llll}1 & 1 & 1\end{array}$

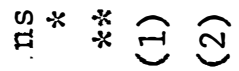


53\% a menos, respectivamente. Isto se deve ao fato da comunida de infestante apresentar teores mais elevados destes elemen tos que o arroz.

o inverso também é verdadeiro quando se examina o exemplo do manganês em que as parcelas no limpo apresentavam maio res quantidades que o conjunto arroz mais comunidade infestante. O arroz apresentou teores altíssimos deste elemento, enquanto que os teores verificados na comunidade infestante foram bem mais baixos. Assim o efeito da comunidade reduzindo a matéria se ca do arroz, näo foi compensado pela quantjdade de manganês prẹ sente nas plantas daninhas e nem pelo efeito positivo desta ülti ma sobre os teores do elemento na planta cultivada (Tabela 06). Com o zinco parece ter havido o mesmo comportamento e como a di ferença de teores näo era muito alta, as quantidades se equivale ram em parcelas puras e nas parcelas no mato. Com relação ao fer ro, novamente a falta de significância deve ser atribuída ao alto coeficiente de variação.

Às doses de fertilização nitrogenada afetaram po sitivamente e de maneira linear as quantidades de matéria seca ( $F=7,03^{*}$ contra $2,89^{\mathrm{ns}}$ da regressão quadrätica), e nitrogênio ( $F=46,89^{* *}$ contra $1,25^{\mathrm{ns}}$ da regressão quadrātica), de potássio $\left(F=16,25^{* *}\right.$ contra $1,11^{\text {ns }}$ da regressão quadrática), e de cobre $\left(F=15,29^{* *}\right.$ contra $1,11^{\text {ns }}$ da regressão quadrätica), acumulados no sistema.

Estes resultados comparados com os observados com a cultura do arroz (Tabela 08), observam diferenças com relação ao 
cálcio e magnésio que naquela ocasião foram afetados pela ferti lização nitrogenada. No entanto observando-se bem, grande parte destes elementos no sistemä encontram-se na comunidade infestan te, a qual não apresentou resposta ao nitrogênio.

Nas parcelas em que a cultura e a comunidade in festante desenvolveram em competição, estudou-se a distribuição da matéria seca e dos nutrientes no sistema e os resultados, com relação ao arroz, estão apresentados na Tabela 11.

Considerando a média de todos os tratamentos participação do arroz na matéria seca do sistema foi em torno de 48\%. Aproximadamente nesta mesma proporção ficaram aqueles nu trientes cujos teores não divergiram muito do arroz para a comu nidade infestante, como o nitrogênio (43\%), o fosforo (50\%), o potássio (45\%), o cobre (48\%). Para áqueles cujos teores eram bem mais elevados no arroz que na comunidade, a participação da cultura foi bastante grande, como é do caso do manganês (86\%) e o zinco (65\%). No entanto, ocorreu o contrário para o ferro (33\%), o cálcio (23\%) e o magnésio (33\%).

Com relação ao nitrogênio, as doses de fertilizą çào nitrogenada alteraram positiva e linearmente a paṛticipação do arroz no sistema $\left(F=6,52^{*}\right.$ contra $1,32^{\text {ns }}$ para a regressão quadrātica) indicando que, à medida que se aumentou a fertiliza çăo nitrogenada, a participação do arroz também aumentou, o que é esperado uma vez que a fertilização foi realizada próxima da linha de semeadura : da planta.

No desdobramento da interação $\mathrm{E} \times \mathrm{N}$ observa-se 


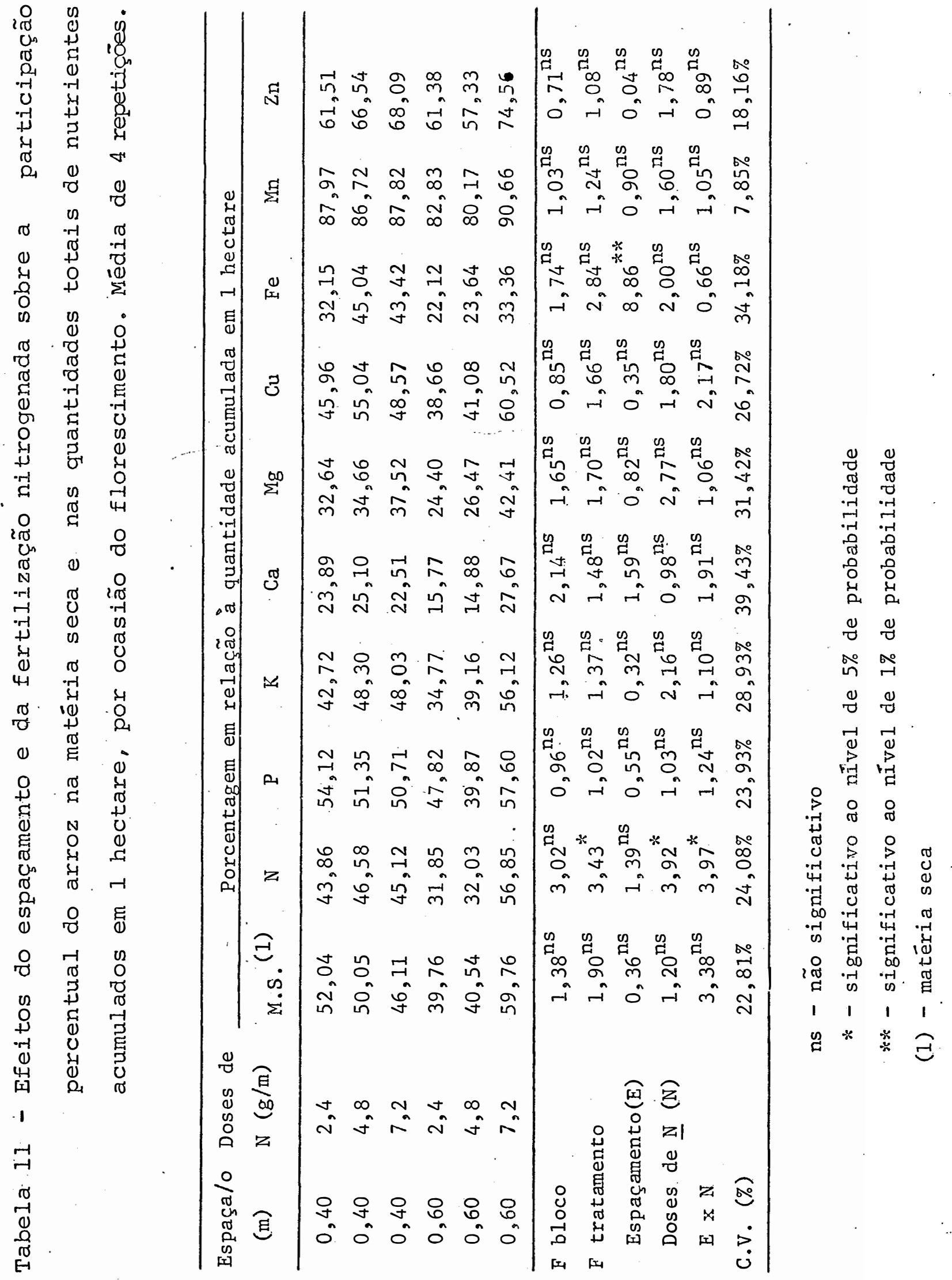


que as doses de nitrogênio influenciaram a participaçäo do

roz apenas no espaçamento de $0,60 \mathrm{~m}$, provavelmente porque no me nor espaçamento a resposta do arroz ao nitrogênió foi, em parte, prejudicada pela competição intraespecífica.

A participação do arroz com relação ao ferro acu mulado pelo sistema, foi significativamente diminuida no espaça mento de $0,60 \mathrm{~m}$. Isto se deve provaxelmente aos mais elevados teores de ferro encontrados na comunidade infestante com relação ao arroz. Assim, no maior espaçamento a participação do arroz é menor, ressaltando os efeitos dos altos teores do elemento na comunidade infestante.

Na Tabela 12 são apresentados resultados, referen tes os teores do nutrientes no arroz beneficiado. Os resultados referentes aos micronutrientes foram duvidosos e, por isso, op tou-se por excluí-los da tabela.

Dentre os macronutrientes observaram-se maiores teores de nitrogênio, depois potássio. A:seguir, os teores de fosforo e magnésio foram equivalentes e, finalmente, o cálcio foì o que apresentou menores concentrações. Os teores de nitrọ gênio são compatíveis aos apresentados por ANGLADETTE (1975) e por MEDEIROS \& MALAVOLTA (1980). Os teores de fósforo e potássio são inferiores aos observados pelos três autores. Todos os ele mentos foram encontrados em níveis inferiores aos observados por MEDEIROS \& MALAVOLTA (1980). E interessante esclarecer que es tes últimos autores utilizaram dé soluções nutritivas como subs trato ao desenvolvimento das plantas. 
Tabela 12 - Efeitos do espaçamento entre sulcos de semeadura, da fertilização nitrogenada e da competição das plantas daninhas sobre os teores de nutrientes na matéria se ca de grãos de arroz beneficiados. Média de 4 repe tições。

\begin{tabular}{|c|c|c|c|c|c|c|c|}
\hline \multirow{2}{*}{ Espaçamento } & \multirow{2}{*}{$\begin{array}{l}\text { Dose de } \\
\mathrm{N}(\mathrm{g} / \mathrm{m})\end{array}$} & \multirow{2}{*}{ Condiçãc } & \multicolumn{5}{|c|}{ Teores (q) } \\
\hline & & & $N$ & $\mathrm{P}$ & $\mathrm{K}$ & $\mathrm{Ca}$ & $\mathrm{Mg}$ \\
\hline 0,40 & 2,4 & Limpo & 1,49 & 0,04 & 0,08 & 0,02 & 0,04 \\
\hline 0,40 & 2,4 & Mato & 1,48 & 0,05 & 0,10 & 0,03 & 0,03 \\
\hline 0,40 & 4,8 & Limpo & 1,34 & 0,05 & 0,08 & 0,02 & 0,03 \\
\hline 0,40 & 4,8 & Mato & 1,64 & 0,04 & 0,11 & 0,03 & 0,06 \\
\hline 0,40 & 7,2 & Limpo & 1,65 & 0,05 & 0,11 & 0,03 & 0,05 \\
\hline 0,40 & 7,2 & Mato & 1,81 & 0,06 & 0,13 & 0,03 & 0,05 \\
\hline 0,60 & 2,4 & Limpo & 1,40 & 0,04 & 0,09 & 0,02 & 0,05 \\
\hline 0,60 & 2,4 & Mato & 1,54 & 0,06 & 0,12 & 0,03 & 0,07 \\
\hline 0,60 & 4,8 & Limpo & 1,34 & 0,05 & 0,09 & 0,03 & 0,04 \\
\hline 0,60 & 4,8 & Mato & 1,51 & 0,06 & 0,12 & 0,02 & 0,08 \\
\hline 0,60 & 7,2 & Limpo & 1,43 & 0,04 & 0,08 & 0,02 & 0,03 \\
\hline 0,60 & 7,2 & Mato & 1,81 & 0,05 & 0,12 & 0,02 & 0,06 \\
\hline F blocos & & & $6,00^{*}$ & $6,31^{*}$ & $8,98^{* x}$ & $1,77^{\mathrm{ns}}$ & $8,12^{* *}$ \\
\hline F tratamen & & & $3,33^{*}$ & $1,70^{\mathrm{ns}}$ & $3,00^{*}$ & $0,12^{\mathrm{ns}}$ & $2,72^{*}$ \\
\hline Espaçame & tos (E) & & $1 ; 73^{\text {ns }}$ & $0,31^{n s}$ & $0,33^{\mathrm{ns}}$ & $1,16^{\mathrm{ns}}$ & $4,79^{*}$ \\
\hline Doses de & $N \quad(N)$ & & $7,67^{* *}$ & $0,04^{\mathrm{ns}}$ & $0,66^{\mathrm{ns}}$ & $0,31^{\mathrm{ns}}$ & $0,19^{\mathrm{ns}}$ \\
\hline Condição & (C) & & $14,33^{* *}$ & $3,94^{\mathrm{ns}}$ & $13,04^{* *}$ & $1,04^{\mathrm{ns}}$ & $11,37^{* *}$ \\
\hline$E \times N$ & & & $0,27^{\mathrm{ns}}$ & $2,32^{\mathrm{ns}}$ & $2,14^{\mathrm{ns}}$ & $2,71^{\mathrm{ns}}$ & $2,01^{\mathrm{ns}}$ \\
\hline$E \times C$ & & & $0,63^{\mathrm{ns}}$ & $0,91^{\mathrm{ns}}$ & $0,49^{\mathrm{ns}}$ & $2,71^{\mathrm{ns}}$ & $4,11^{\mathrm{ns}}$ \\
\hline $\bar{N} \times C$ & & & $1,47^{\mathrm{ns}}$ & $0,36^{\mathrm{ns}}$ & $0,08^{\mathrm{ns}}$ & $1,69^{\mathrm{ns}}$ & $2,30^{\mathrm{ns}}$ \\
\hline$E \times N \times$ & & & $1 ; 11^{\mathrm{ns}}$ & $0,70^{\mathrm{ns}}$ & $0,05^{\mathrm{ns}}$ & $2,31^{\mathrm{ns}}$ & $0,30^{\mathrm{ns}}$ \\
\hline C.V. (q $)$ & & & $11,28 \%$ & $49 ; 518$ & 23,958 & 37,338 & $50,89 q$ \\
\hline
\end{tabular}


A presença das plantas daninhas influiu favoravel mente sobre os teores de nitroyênio, potássio e magnésio na cariopse descascada. De acordo com CHISARA (1977), um dos prin cipais efeitos da competição das plantas daninhas é a diminui ção do número de cariopses por panícula. Este poderia ser uma ex plicação para o aumento da concentração dos nutrientes nos gräos de arroz.

Ao contrário do que ocorreu com relação a parte aérea do arroz; os teores de magnésio nos grãos foram maiores no espaçamento de $0,60 \mathrm{~m}$. E provavel que no espaçamento de $0,60 \mathrm{~m}$ a influência das plantas daninhas tenha sido maior na formação da panícula, ocorrendo maior efeito de concentração.

Observa-se ainda que a'fertilização nitrogenada afetou linear e positivamente os teores de nitrogênio noṣ grãos . $(F=$ $10,07^{* *}$ contra $0,57^{\text {ns }}$ da regressão quadrática).

Na Tábela 13 são apresentados os resultados refe rentes à produção da cultura do àroz e as quantidades acumula das por hectare dos macronutrientes.

A produtividade da cultura näo foi influenciada pelo espaçamento entre sulco de semeadura e pela fertilização nitrogenada. A competição imposta pelas plantas daninhas reduziu a produção da cultura, em torno de $60 \%$ e com isso, reduziu sig nificativamente a quantidade acumulada de todos os nutrientes por unidade de ārea. A queda de produção foi alta a ponto de não ser possível que as diferenças de concentração dos elementos no grão alterem o comportamento de qualquer nutriente analisado fren 
Tabela 13 - Efeitos do espaçamento entre sulcos de semeadura, da fertilização, nitrogenada e da competição das plantas daninhas sobre as quantidades de nutrientes pre sentes na produção por hectare de grãos beneficiados do arroz. Média de $4 \cdot$ repetições.

Espaça/o Dose de Condição Produção Quantidade (kg/ha)

\begin{tabular}{|c|c|c|c|c|c|c|c|c|}
\hline (m) & $\mathrm{N}(\mathrm{g} / \mathrm{m})$ & & $\mathrm{kg} / \mathrm{ha}$ & $\mathrm{N}$ & $\mathrm{P}$ & $\mathrm{K}$ & $\mathrm{Ca}$ & $\mathrm{Mg}$ \\
\hline 0,40 & 2,4 & Limpo. & 2895,15 & 42,93 & 1,14 & 2,27 & 0,61 & 0,99 \\
\hline 0,40 & 2,4 & Mato & 804,22 & 11,52 & 0,40 & 0,83 & 0,20 & 0,26 \\
\hline 0,40 & 4,8 & Limpo & 2334,68 & 31,00 & 1,06 & 1,94 & 0,47 & 0,70 \\
\hline 0,40 & 4,8 & Mato & 1070,08 & 16,90 & $0,43$. & 1,02 & 0,29 & 0,55 \\
\hline 0,40 & 7,2 & Limpo & 2743,95 & 45,22 & 1,32 & 2,89 & 0,88 & 1,36 \\
\hline 0,40 & 7,2 & Mato & 1332,45 & 22,74 & 0,68 & 1,41 & 0,49 & 0,66 \\
\hline 0,60 & 2,4 & Limpo & 2525,72 & 35,30 & 1,16 & 2,40 & $0,5 \dot{5}$ & 1,26 \\
\hline 0,60 & 2,4 & Mato & 799,0 & 12,29 & 0,44 & 0,92 & 0,25 & 0,50 \\
\hline 0,60 & 4,8 & Limpo & 2270,10 & 30,29 & 1,09 & 2,07 & 0,68 & 0,80 \\
\hline 0,60 & 4,8 & Mato & 895,37 & 13,50 & 0,60 & 1,12 & 0,14 & 0,70 \\
\hline 0,60 & 7,2 & Limpo & 2408,30 & 33,68 & 0,90 & 1,85 & 0,39 & 0,76 \\
\hline 0,60 & 7,2 & Ma to & $963 ; 02$ & 17,10 & 0,44 & 1,12 & 0,20 & 0,60 \\
\hline \multicolumn{3}{|c|}{ F bloco } & $0,88^{\mathrm{ns}}$ & $0,35^{\mathrm{ns}}$ & $4,00^{*}$ & $0,43^{\mathrm{ns}}$ & $1,40^{\text {ns }}$ & $0,01^{\mathrm{ns}}$ \\
\hline \multicolumn{3}{|c|}{ F tratamentos' } & $15,33^{* *}$ & $14,42^{* \%}$ & $5,22^{*}$ & $4,23^{*}$ & $4,20^{*}$ & $2,17^{*}$ \\
\hline \multicolumn{3}{|c|}{ Espaçamentos (E) } & $3,16^{\mathrm{ns}}$ & $6,67^{*}$ & $0,53^{\text {ns }}$ & $0,58^{\mathrm{ns}}$ & $3,72^{n s}$ & $0,02^{\mathrm{ns}}$ \\
\hline \multicolumn{3}{|c|}{ Doses de $N(N)$} & $1,05^{\mathrm{ns}}$ & $4,71^{*}$ & $0,12^{\mathrm{ns}}$ & $0,79^{\mathrm{ns}}$ & $1,80^{\mathrm{ns}}$ & $0,57^{\text {ns }}$ \\
\hline \multicolumn{3}{|c|}{ Condiçäo (C) } & $157,66^{* *}$ & $130,10^{* * *}$ & $50,78^{\frac{1}{*} *}$ & $37,88^{* *}$ & $27,20^{* *}$ & $12,50^{* * *}$ \\
\hline \multicolumn{3}{|c|}{$\mathrm{E} \times \mathrm{N}$} & $0,31^{\mathrm{ns}}$ & $1,19^{\mathrm{ns}}$ & $2,41^{\mathrm{ns}}$ & $1,86^{\mathrm{ns}}$ & $3,37^{\mathrm{ns}}$ & $2,06^{\mathrm{ns}}$ \\
\hline \multicolumn{3}{|c|}{$E \times C$} & $0,09^{\mathrm{ns}}$ & $1,12^{\mathrm{ns}}$ & $0,48^{\mathrm{ns}}$ & $0,37^{\mathrm{ns}}$ & $0,03^{\mathrm{ns}}$ & $0,60^{\mathrm{ns}}$ \\
\hline \multicolumn{2}{|c|}{$N \times C$} & & $2,14^{\mathrm{ns}}$ & $3,58^{\mathrm{ns}}$ & $0,43^{\mathrm{ns}}$ & $0,67^{\mathrm{ns}}$ & $0,12^{\mathrm{ns}}$ & $2,11^{\mathrm{ns}}$ \\
\hline \multicolumn{2}{|c|}{$E \times N \times C$} & & $0,35^{\mathrm{ns}}$ & $0,86^{\mathrm{ns}}$ & $0,08^{\mathrm{ns}}$ & $0,46^{\mathrm{ns}}$ & $1,80^{\mathrm{ns}}$ & $0,91^{\mathrm{ns}}$ \\
\hline \multicolumn{3}{|c|}{ C.V. (\%) } & $24,42 \%$ & $24,19 \%$ & $37,29 \%$ & $39,65 \%$ & $51,93 \%$ & $55,73 \%$ \\
\hline
\end{tabular}

ns - não significativo

* - significativo ao níve1 de $5 \%$ de probabilidade ** - significativo ao níve1 de $1 \%$ de probabilidade 
te aos efeitos dos tratamentos. E interessante esclarecer que, esta queda de produçäo apresentada pela cultura, não é fruto ex clusivo da competição por nutrientes. A estes foram adicionados os efeitos da competição por água e luz.

Os resultados da presente pesquisa mostraram que a comunidade infestante competiu por nutrientes com a cultu ra do arroz de sequeiro e que esta competição dependia do nu triente em questão, envolvendo principalmente as exigências a presentadas tanto pela cultura como pelas plantas daninhas pre sentes.

As doses de fertilização nitrogenada, utilizadas de maneira geral, incrementou os teores de alguns elementos na planta e favoreceu o do crescimento da cultura, sem contudo in fluenciar a produção.

A redução do espaçamento entre sulcos de semeadu ra proporcionou uma competição intraespecífica, o que limitou as respostas do arroz à feertilização nitrogenada e tambēm influência de maior número de plantas de arroz sobre a comunida de infestante. Além disso, pelo fato de não haver sido feito um controle inicial da comunidade infestante, o efeito do espaça mento foi diminuindo em termos de incremento da competiti vidade da cultura.

Aconselha-se que em pesquisas posteriores, nas parcelas em que haverá competição, um controle inicial da comu nidade infestante. Recomenda-se ainda que, em menores espaçamen tos reduza-se a densidade de semeadura (mantendo a população por 
hectare), para evitar que a competição intraespecífica comprome ta os propósitos da pesquisa. 
6. CONCLUSÕES

Nas condiçöes em que foi desenvolvida a presente pesquisa pode-se concluir que:

1. A competição imposta pelas plantas daninhas re duziu os acúmulos de matéria seca e de nutrientes na parte aérea e nos grãos de arroz. A redução da produção foi da ordem de $60 \%$ :

2. os acúmulos de matéria seca e de nutrientes pe la comunidade infestante não foram alterados pelo espaçamento e pela fertilização nitrogenada;

3. as participações do arroz e da comunidade in festante no total da matéria seca acumulada no sistema foram equilibradas;

4. a comunidade infestante e a cultura divergiram 
no recrutamento dos recursos minerais do solo. O arroz apresen tou teores mais elevados de fósforo, cobre, manganês e zinco. Os teores de nitrogênio, potássio, cálcio, mangnésio e ferro foram maiores na comunidade infestante;

5. a intensidade de influência das plantas dani nhas em relaçăo aos teores dos elementos no arroz foi maior no espaçamento de $0,60 \mathrm{~m}$ e dependeu do nível de exigência dos compe tidores em relação aos elementos. 
7. SUMMARY

NUTRIENT WEED COMPETITION IN UPLAND RICE CROP. ROW SPACING AND NITROGEN FERTILIZATION EFFECTS。

Candidate: Robinson Antonio Pitelli Adviser: Henrique Paulo Haag

The purpose of this work was the study of the row spacing, from 0.40 to $0.60 \mathrm{~m}$, and nitrogen doses, 2.4, 4.8 and $7.2 \mathrm{~g}$ of $\mathrm{N} / \mathrm{m}$ of row, effects on the weed competition for nitrogen, phosphorus, potassium, calcium, magnesium, copper, iron, manganese and zinc, in upland rice crop (Oryza sativa L. cV. IAC 25). The experiment was instalated in a "Latossol Ver melho Escuro fase arenosa" soil. 
The rice plants and weed shoots were coleted in the tillering and flowering crop phases, and chemically analize ted. The rice grains were also analizeted.

In our experimental conditions the following con clusions seams to hold:

1) The weed competition reduced the acumulation of dry matter, nutrients in shoot and in the rice grains. The yield was reduced about 60 per cent;

2) the dry matter and nutrient acumulation in the weed community had not been afected by crop row spacing and nitrogen fertilization:

3) the relative dry matter distribuition between the rice crop and weed community in the total dry matter of the system were equilibrated;

4) there were differences in the mineral uptake by the weeds and rice crops. The levels of phosphosus, copper, manganese and zinc were higher in rice plants. Contrasting, the levels of nitrogen, potassium, calcium, magnesium and iron that were higher in the weed community;

5) the degree of the effects of the weed competi tion in relation to the levels of nutrients were higher in $0,60 \mathrm{~m}$ spacing. The effect was dependent of the nutricional re queriment levels of each element by the competidors. 
8. LITERATURA CITADA

AHMAD, S.; A. MAJID \& M. RACHID., 1977. Rice weed competition under different fertily levels. Agriculture Pakistan 28(2) : $147-152$ 。

ALOISI, R.R。 \& J.L.I.DEMATTÉ, 1974。 Levantamento dos solos da Faculdade de Medicina Veterinária e Agronomia de Jaboticabal. Cientifica $02(1): 123-136$.

ANGLADETTE, A., 1975. El arroz: Barcelona, Editorial Blume, $432 \mathrm{p}$.

ARAI, M. \& R. KAWASHIMA, 1956. Ecological studies on weed dama ge of rice plants in rice cultivation. Proceedings of Crop Science Japan 25: 115-119.

BANTILAN, R.T.; M.C. PALADA \& R. HARWOOD, 1974. 
weed management. I. Key factors affecting crop-weed balance . In: Annual Convention of the Pest Control Council of The Philippines, 5\%, Davao City. Isolated Paper, 9. pp. BANGLADESH, Blangladesh Rice Research Institute, 1977.

Annual

Report for 1974-75. Dacca, BRRI Press. 99 pp. Apud: Weed Abstracts $30(4): 1446,1981$.

BLANCO, H.G., 1972. A importância dos estudos ecológicos nos programas de controle de plantas daninhas. Biológico, 38: $343-350$.

BLANCO, H.G., 1975. Catalogo das espëcies de mato -infestantes de āreas cultivadas no Brasil. Gramineas de ciclo anual. Bio Zógico 41: 6-14.

BLEASDALE, J.K.A., 1960。 Studies on plant competition. In: HAR PER, J.L. The Biology of Weeds. Oxford, Blackwell Scien tific Publication, p. 133-142.

BRADY, N.C., 1979. Overview of tine rice pest problems. In: International Congress of Plant Protection and Annual Meeting of the American Phytopathological Society, $71^{\text {st }}$, Washington, Abstracts, p. 266 .

BUA-GNAM, T. \& B. MERCADO, 1976. Competition of water lettuce (Pistia stratrates) with rice and commonly associated weed species. Philippine Agriculturalist 60: 22-30.

CERRIZUELLA, E.A.\& R.À.AREVALO, 1974. Efectos de la competen cia de malezas sobre la fertilization nitrogenada em cana-de-azúcar. Revista Agronomica del Noroeste Argentino ll (3/4): $179-191$. 
CICEREALI, L.G.; R.A. PITELLI; W.J.MELO \& H.P. HAAG, 1978. Com posição quịmica de algumas plantas infestantes da cultura do milho. In: Seminário Brasileiro de Herbicidas e Ervas Dani nhas, 128, Fortaleza. Resumos, p. 121.

CHANG, W.L., 1969. Progress report on rice weed control

experi ments and extension in Taiwan. In: Asian-Pacific Weed Control Interchange, 2a: Taiwan. Proceedings,pp. 60-71.

CHISAKA, H., 1966. Competiton between rice plants and weeds. Weed Research Japan 5: 16-22.

CHISAKA, H., 1977. Weed damage to crops: yield loss due to weed competition. In: FRYER, J.D. \& S. MATSUNAKA, Edit. Inte grated Control of Weeds. Tokyo, University Tokyo Press. pp. $1-16$.

COMISSÃO DE. SOLOS. Levantamentó de réconhecimento dos solos do Estado de São Paulo e Rio de Janeiro, C.N.E.P.A./SNPA, 639p. (Boletim 12).

DE DATTA, S.K. \& J. MALABUYOC, 1976. Nitrogen response of lowland and upland rice in relation to tropical environment conditions., In: Symposium on Climate and Rice, Los Baños. Proceedings, p. 509-539.

DOMINGUES, E.P., 1981. Efeitos do espaçamento e da fertilização nitrogenada sobre as relações competitivas entre a comunidade infestante e a cultura do arroz de sequeiro (Oryza sativa L.). Jaboticabal, FCAV/UnESP, p.86. (Trabalho de Graduação) . EL-SHAFHEY, Y.H.; H. EL-HATTAB \& N.O. MONGED, 1975. NPK content of maize plant and associated weeds as affected by nitrogen 
levels. Iridian Journal of Agricultural science 45(7): 316-320 .

FILIPINAS. Internationai Rice Research Institute, 1974. Annual Report for 1973. Los Baños, IRRI Press. pp. 20-30 e 78-32.

GALLO, J.R.; F.R.P. MORAES; W.L. LOTT \& R. INFORZATO, 1958. Ab sorção de nutrientes pelas ervas daninhas e sua competição com o cafeeiro. Campinas, Instituto Agronomico, Boletim no 104. $13 \mathrm{pp}$.

GARGANTINI, "H.; BLANCO, H.G., 1965. Absorção de nutrientes pela cultura do arroż. Bragantia 24 (38): 515-19.

GUH, J.O., 1973. Sucessive growth of weeds as affected by soil fertility and light intensity in paddy fields fertilized dif ferently for many years. Seoul University Faculty Papers 3 (3): 1-34. Apud: Weed Abstracts, 29.(3): 607, 1980. HOLM, L.G.; D.L. PLUCKNETT, J.V. PANCHO \& J.P. HERBERGER, 1977 • The world's worst weeds. Distribuition and biology. Hondulu, University Press of Havaii, 609 pp.

HOVELAND, C.S.; G.A. BUCHANAM \& M.C. HARRIS, 1976. Response of weeds to soil phosphorus and potassium. Weed Science 24(2); 194-201.

JENNINGS, P.R., 1966. The evolution of plant type in Oryza sa tiva. Economic Botany 20: 396-402.

KAKATI, N.N.\& V.S. MANI, 1977. Chemical weed control in rice in relation to fertilizer use. In: Weed Science Conference and Workshop in India, New Dehli. Abstracts, paper no 1l, p. 10. Apud: Weed Abstracts 27(10): 3599 . 
KAUSHIK, S.K. \& V.S. MANI, 1977. Investigations on chemical weed control in direct seeded and transplanted rice.

In: Weed Science Conference and Workshop in India, New Dehli . Abstracts, paper no 15, p.10. Apud: Weed Abstracts 27(10): 3598 .

KAWANO, K॰; H. GONZALEZ \& M. LUCENA, 1974. Intraspecific compe tion, competition with weeds and spacing response in rice. Crop Science 14: 841-845.

KIM, S.C.; H. HEU, R.K. PARK \& S.Y。JAE, 1977. Studies

on competition between major perennial weeds and rice in trans planted paddy fields. Journal of Korean Society of Crop Science 22(1): 61-69. Apud: Weed Abstracts 28(11): 3612,1979. KIM, S.C. \& K. MOODY, 1980. Study on the residual effect OI plant spacing and weeding treatment on the weed flora. Re search Report of the Office of Rural Development 22: 76-81.

LINDSAY, W.D., 1972. Zinc in soils and plant nutrition. Advan ces in Agronomy 24: 147-186.

LONG, D.V. \& J. ALKAMPER, 1978. Influence of the various weeds on crops yields under increased fertilization. Medelingan van de Fakulteit Landbowwetenschappen Gent 43 (2): 1085-1096. Apud: Weed Abstracts 28(12): 4122, 1979.

MEDEIROS, A.A. \& E. MALAVOLTA, 1980. Exigências nutricionais do arroz (Oryza sativa L. CV. I.A.C. 47 e I.A.C.435). Anais da E.S.A. "Luiz de Queiroz" 37: 401-418.

MERCADO, B.L. \& R.T. LUBIGAN, 1979. Biology and Control of Paspalum distichum L. 3. Competition with lowland rice. In: 
University of Philippinas, Weed Science Report for 1977-78. Los Baños University Philippinas Press. 108 pp. Apud: Weed Abstiracts $29(2): 524$.

MUKHOPADHYAY, S.K.; A.B. KHARA \& B.C. GHOSH, 1972. Nature and intensity of competition of weeds with diret seeded IR8 rice crop. International Rice Commission Wewsletter 2l(2): 10-14 .

MYERS, L.F。\& R.M. MOORE, 1952. The effect of fertilizer on a winter weed population. Journal of Australian Institute of Agricultural Science: 18: 152-155.

NIETO, H.J. \& D.W. STANIFORTH, 1961. Corn-foxtail competition under various production conditions. Agronomy Journal 53: $1-5$.

NODA, K॰, 1973. Competitive effects of barnyard grass ( Echinochloa cruz-galli) on rice. In: Asian-Pacific Weed Science Society Conference, 4th, Rotoria. Proceedings, pp. 145-150. NODA, K., 1977. Integrated weed management in rice. In: FRYER, J.D. \& MATSUNAKA, Edit. Integrated Control of Weeds. Tokyo University Tokyo Press, pp. 17-46.

NOGUCHI, K. \& K. NAKAYAMA, 1978a. Effects of fertilization on growth of main upland weeds. Weeds Research Japan 23(4): 175-180. Apud: Weed Abstracts 28(12): 4116, 1979. NOGUCHI, K. \& K: NAKAYAMA, 1978b. Studiēs on competition bet ween upland crops and weeds. 3. Effects of shade on growth of weeds. Japanese Journal of Crop Science $\underline{47(1): 56-62 .}$ OKAFOR, L.I., 1973. Perennial nutsedge (Cyperus rotundus L.)com 
petiton with upland rice and its chemical control. Los Ba nos, University od Philippines. MSc Thesis, 207 pp. Apud: Weed Abstracts 23(9): 1898, 1974 .

OKAFOR, L.I. \& S.K. DE DATTA, 1976. Competition between upland rice and purple nutsedge for nitrogen, moisture and light. Weed Science 24 (1): 43-46.

PARFENYUK, A.A., 1975. The timing and method of applying Yalan and Izofos in rice crops. Khimiya v Sel'skom Khozyaistve $\underline{13}$ (1) : 36-39. Apud: Weed Abstracts 25(2): 432, 1976.

RAIJ, B. van \& ZULLO, M.A.T. Métodos de anālise de solo. Cam pinas, Instituto Agronômico, Circular 63; 16 p., 1977.

ROGERS, L.H.; O.E.GAIL, \& R.M. BARNETTE, 1939. The Zinc Con tent of weeds of volunteer grasses and planted land covers. Soir Sciencè, 47: 237-242。

SARKAR, P.A., 1979. Study of varietal response to planting geo metry and weeding in transplanted rice. Allahabad Farmer 50: $357-358$.

SARRUGE, J.R. \& H.P.HAAG, 1974. Análises quimicas em plantas. Piracicaba, ESALQ, 56.p. (mimeografado).

SILVA, J.A., 1977. Crescimento e absorção de nutrientes por Euphorbia heterophyzla L. (amendoim-bravo). Jaboticabal, FCAV/ /UNESP, 50 pp. (Trabalho de Graduação).

SINGLACHAR, M.A., T.H. SHIVAPPA \& V. BHASKAR RAO, 1978. Effects of free weed duration on the performance of dwarf and tall rices types. Mysocre Journal of Agricultural Sciences 12: 210 -212 . 
SMITH, R.J. \& W.C. SHAW, 1966. Weeds and their control in rice production。 USDA Agricultural

SWAIN, D.J.; M.J. NOTT \& R.B.TROUNCE, 1975. Competition bet ween Cyperus differmis and rice: the effect of time of weed removal. Weed Research 15: 149-152.

TAKAYANAGI, S.; T. UDAGAWA; G. TAKEDA \& H. IWAKI, 1974. Model simulation of interspecific competition between to plant species in relation to light environment. Crop science so ciety of Japan 43(4): 538-549. Apud: Weed Abstracts 25(3): 803, 1976 .

YAMAGISHI, A。; A. HASHIZUME \& Y. TAKEICHI, 1976. Studies on the control of perenial weeds in paddy fields. Competition between Cyperus serotinus Rottb and rice. Bulletin of the Chiba-ken Agricultural Experimental Station. Boletim no 17, p. 1.2 .

YAMAGISHI, A. \& Y. TAKEICHI, 1978. Studies on the control of perennial weeds in paddy fields. On the physiological and ecological characteristics of water chesnut (Eleocharis ku roguwai). Chiba-ken Agriculturai Experimental station, Bulle tin no 1.9. pp. 191-217. Apud: Weed Abstracts 29(7): 2094 . YOSHIDA, S., 1975. Factors that limit the growth and yields of upland rice. In: FILIPINAS, IRRI. Major Research in Upland kice. Los Banōs,, IRRI Press, pp. 46-71.. YOSHIDA, S., 1977. Physiological consequences of altering plant type and maturity. International Rice Comission Newsletter 26 (1): 5-16 . 
WEILAND, R.T. \& C.A. STUTTE, 1978. Nitrogen loss with transpirations in several crop and weed species. Arkansas Farm Research 27(2): 16 .

WILLIAMS, E.D., 1977. Growth of seedlings of Agropyron repens L. Beauv. and Agrotis gigantea Roth in wheat and barley: effect of time of emergence, nitrogen supply and cereal seed rate. Weed Research 17: 69-76. 